\title{
Disorganized attachment in early childhood: Meta-analysis of precursors, concomitants, and sequelae
}

\author{
MARINUS H VAN IJZENDOORN, CARLO SCHUENGEL, AND \\ MARIAN J BAKERMANS-KRANENBURG \\ Leiden Unlversity
}

\begin{abstract}
Durıng the past 10 years nearly 80 studies on disol gamuzed attachment involving moie than 6000 infant-paient dyads have been carned out The cuivent series of meta-analyses have established the reliability and disciımmant validity of disolganized infant attachment Although disorganized attachment behavion is necessarily difficult to observe and often subtle, many reseatchers have managed to become reliable codeis Fuitheimote, disolganized attachment shows modest shoit-and long term stability, in paticular in middle class environments and it is not just a concomitant of constitutional, temperamental, or physical child problems The predictive validity of disorganized attachment is establıshed in terms of pioblematic stress management, the elevated risk of externalızıng problem behavior, and even the tendency of disorganized infants to show dissociative behavior later in life In notmal middle class families about $15 \%$ of the infants develop disorganized attachment behavio1 In other social contexts and in clinical groups this percentage may become twice or even thiee times higher (e $\mathrm{g}$ in the case of maltreatment) Although the importance of disorganized attachment for developmental psychopathology is cvident the seaich for the mechanisms leading to disoiganization has just started Firghtenng parental behavior may play an important role but it does not seem to be the only causal factor involved in the emergence of disotganized attachment
\end{abstract}

An important developmental milestone in every child's life is the formation of an attachment bond to the parent (Sioufe, 1988) In attachment theory, it has been proposed that

This paper is based on an inviled contibution to the ex pert meeting of the National Institute of Mental Health (NIMH) on "Assessment of Infant and Toddler Mental Health Advancing a Research Agenda by Integrating Basic and Clinical Approaches,' Bethesda, Octobe1 6-7 1997 The authors acknowledge the statistical assistance of Dr Pieter Kroonenberg and the thoughtful comments of the reviewers on an earlier version of this paper We are gratefui to the authors of the primary studies who provided us with additional raw data, and to Dr Mary Main and Di Karlen Lyons-Ruth who commented on eallei versions of this paper in detal

Address correspondence and tepunt requests to $\mathrm{Mar}$ inus $H$ van IJzendoorn, Center for Child and Family Studies, Leiden University, PO Box 95552300 RB Leiden The Netherlands E mail Vanijzen@1ulfsw leıdenunıv $\mathrm{nl}$ duing the first year of life infants leain to deal with stiessful circumstances and negative emotions in organized manners Avordantly attached infants ate suggested to minimize the expression of negative emotions in the piesence of a parent whom they would have experienced to be rejecting or ignoing such emotions Ambivalently attached infants are considered to maximize the expression of negative emotions and the display of attachment behaviors, in order to draw the attention of their supposedly inconsistently iesponsive parent They may remain passively or angrily focused on thell parent even when the envi1onment calls for exploration and play (Main, 1990) In a stressful situation, securely attached infants may express their distiess to the parent who would be able to provide comfort and to serve as a safe base for exploration (Ainsworth, Blehar, Waters, \& Wall, 1978, 
Dozier \& Kobak, 1992). Securely attached children are suggested to strike a balance between seeking proximity to their attachment figure and their inclination to explore the wider environment. These three "organized" attachment strategies (A, B, and C; Ainsworth et al., 1978) may be considered as adaptive to the infants' environments, and each is supposed to allow for a maximum of proximity to the specific attachment figure whose behavior to stress or distress is anticipated (Main, 1990).

The concept of "disorganized" attachment emerged from the systematic inspection of about 200 cases from various samples that were difficult to classify in one of the three organized attachment categories (Main \& Solomon, 1986). In particular, in studies on maltreated infants, the limits of the traditional Ainsworth et al. (1978) coding system became apparent because many children with an established background of abuse or neglect nevertheless had to be forced into the secure category (Carlson, Cicchetti, Barnett, \& Braunwald, 1989). Common denominator of the anomalous cases appeared to be the (sometimes momentary) absence of an organized strategy to deal with the stress of the Strange Situation procedure. Disorganized attachment therefore may be defined negatively-against the background of how children with organized strategies deal with a stressful situation in the presence of their parent or other caregiver (Main, 1990). Disorganized attachment can be described as the breakdown of an otherwise consistent and organized strategy of emotion regulation. Whether secure or insecure, every child may show disorganization of attachment depending on the earlier child rearing experiences (Main \& Hesse, 1990). In some cases, the disorganization of attachment is so predominant that a secondary, organized strategy cannot be detected. Disorganization of attachment is usually considered a type of insecure attachment, independent of the secondary classification.

Although disorganized attachment behaviors are most easily defined in opposition to organized attachment strategies, the Main and Solomon (1990) coding system provides sev- eral concrete behavioral indices that in and of themselves qualify the infant for a disorganized attachment classification. Contradictory behavior, misdirected or stereotypical behavior, stilling and freezing for a substantial amount of time, and direct apprehension or even fear of the parent are behavioral indices of disorganized attachment in particular when they occur in stressful circumstances in the presence of the parent and with a sufficient degree of intensity (Main \& Solomon, 1990). Contradictory behavior, for example, can be observed when the infant shows indifference upon mother's return after excessive distress during separation. Misdirected behavior may consist of seeking proximity to the stranger instead of the parent after separation. Stereotypical behavior concerns, for example, the repeated pulling of hair with a dazed expression in a context in which the child is clearly stressed and the parent is available. Freezing means that the child, unable to choose between seeking proximity or avoiding the parent, stops moving for several moments as if in trance and dissociated from the regular thought processes (Hesse \& Main, in press; Main \& Morgan, 1996). Apprehension means showing fear of the parent immediately upon return after a brief separation, for example by a hand-to-mouth movement. Disorganized attachment behaviors are not just bizarre and incoherent; they are considered to be indicators of an experience of stress and anxiety which the child cannot resolve because the parent is at the same time the source of fright as well as the only potential haven of safety. In the face of this paradoxical situation, the infants' organized strategy to deal with stress is expected to fall apart (Main \& Hesse, 1990). The essence of disorganized attachment is fright without solution (Hesse \& Main, in press).

Maltreating parents, for example, are supposed to create disorganized attachment in their infants because they confront their infants with a pervasive paradox: they are potentially the only source of comfort for their children, whereas at the same time they frighten their children through their unpredictable abusive behavior. The parent is thought to be a source of fear for the child and at the 
same time the only attachment figure who can provide relief from distress. The incompatible behaviors of flight and proximity seeking are proposed to lead to temporary breakdown of organized attachment behavior. Disorganization of attachment, however, does not only occur in families with a maltreating parent but has also been found to develop when the parent is struggling with unresolved loss of an attachment figure or with other traumatic experiences (see Van Ijzendoorn, 1995, for a review). Main and Hesse (1990) speculate that otherwise "normal" parents with unresolved loss may show behavior that is frightening for their infants - against their intentions. These parents may involuntary remember the loss of an important attachment figure and reexperience the fright involved in the loss. The sudden and unexpected display of parental fright is supposed to be frightening for the infant who is unaware of its cause. Children with disorganized attachment are more liable to stress in infancy (Hertsgaard, Gunnar, Erickson, \& Nachmias, 1995; Spangler \& Grossmann, 1993). They may become more aggressive in kindergarten (Lyons-Ruth, 1996), and they may even become vulnerable to altered states of mind such as absorption (Hesse \& van Ijzendoorn, 1998) and dissociation in young adulthood (Carlson, 1998). In this respect, disorganization of attachment is considered to be a major risk factor in the development of child psychopathology (Boris, Fueyo, \& Zeanah, 1997; Lyons-Ruth, 1996; Zeanah, Boris, \& Larrieu, 1997; Zeanah, Boris, \& Scheeringa, 1997).

In the current meta-analysis, we describe the frequency of disorganized attachment in non-clinical and clinical groups, and address the following hypotheses. First, although disorganized attachment may be more unstable because of changes in the environment than the organized attachment patterns, we expect it to be a rather stable phenomenon across time. Second, we expect that disorganized attachment does not originate from physical problems in the child, and that it is not associated with constitutional or genetic characteristics such as sex or temperament. Neurological abnormalities, however, may lead to pseudodisorganized behavior, for example, in autistic or Down's children (Vaughn, Goldberg, Atkinson, \& Marcovitch, 1994), and the coding system explicitly requires the exclusion of this potential cause (Main \& Solomon, 1990; Pipp-Siegel, Siegel, \& Dean, 1997). Third, we hypothesize that the antecedents of disorganized attachment are related to specific behavioral and mental problems in the parents such as maltreatment, unresolved loss or trauma, depression, and marital discord, which may confront the child with an attachment figure who is unpredictably frightening. Disorganized attachment is not just the consequence of insensitive parenting. Fourth, we expect that the sequelae of disorganized attachment concern elevated psychophysiological reactions to stressful circumstances, the display of externalizing problem behavior, and the inclination to enter into somewhat altered states of mind such as absorption or even dissociation.

In sum, through a series of meta-analyses on the available empirical evidence we test the validity of disorganized attachment.

\section{Method}

\section{Selection of the studies}

To identify studies for inclusion in the metaanalysis we applied two search strategies: Systematic computerized searches on the topic of disorganized attachment, and manual search procedures involving the references lists of review articles (e.g., Lyons-Ruth, 1996) and empirical papers. Psychological Abstracts and the Social Sciences Citation Index were used to locate studies. We found nearly 80 studies on more than 100 samples with 6,282 parent-child dyads and 1,285 disorganized attachment classifications. Several publications included the same sample, for example in the case of longitudinal studies (Easterbrooks, Davidson, \& Chazan, 1993; Lyons-Ruth, Alpern, \& Repacholi, 1993; Lyons-Ruth \& Block 1996; Lyons-Ruth, Easterbrooks, \& Cibelli, 1997). In these cases, the sample was included only once in every metaanalysis. Each study had to meet two criteria for inclusion in the meta-analysis.

First, the study should report on an empiri- 
cal investigation of disorganized attachment (Main \& Solomon, 1990) or its equivalents (A/C attachment, Crittenden, 1988, 1992; controlling attachment, Cassidy \& Marvin with the MacArthur Working Group on Attachment, 1989; Main \& Cassidy, 1988; Main, Kaplan, \& Cassidy, 1985). The controlling attachment category in which children attempt to control their interaction with the parent through punitive, overbright, or rejecting behavior, has been suggested to be developmental equivalent to disorganized attachment in the case of older children ( $>2$ years; see Greenberg, Speltz, \& DeKlyen, 1993; Main \& Cassidy, 1988; Main et al., 1985). From the perspective of the Main and Solomon (1990) coding system, the $\mathrm{A} / \mathrm{C}$ pattern is in line with the disorganized sequential display of contradictory behavior patterns. The $\mathrm{A} / \mathrm{C}$ pattern is proposed to be a subcategory of disorganized attachment that may be particularly prevalent in maltreated toddlers. Studies on the A/C pattern may underestimate the amount of disorganized behavior, and therefore lead to conservative estimates of the effect sizes. In the following meta-analyses, we will separately report on the combined effect sizes for the original Main and Solomon (1990) coding of disorganized attachment.

Secondly, the study should report the data in sufficient detail to allow for computations of effect sizes for the dichotomous variable: disorganized attachment versus organized attachment strategies (A, B, and C), or for the continuous rating scale of disorganized attachment (see Main \& Solomon, 1990). To categorize disorganized attachment, the Main and Solomon (1990) coding system prescribes the coding of a continuous scale for disorganization and recommends a cut-off score. This procedure means that categorical and continuous D scores are considered equivalent. The categorical scores may suffer from restriction of range.

We did not restrict the studies to North America but also included studies on disorganized attachment from several European countries and even from developing nations. The participants in the studies come from various ethnic, socioeconomic, and cultural back- grounds. In meta-analysis, moderator variables take this diversity into account and allow for tests of its influence on the combined effect size. Although no study on disorganized attachment is without flaws and drawbacks we decided to include all available studies regardless of their methodological merits (Hedges, 1986; Mullen, 1989). Some study characteristics related to the validity issue such as sample size were included in moderator analyses. Multiple outcomes within one study were combined before this study was added to the main set of studies for further analysis. In many cases the pertinent statistics had to be derived and recomputed from indirect data provided by the papers, such as the test of sex differences. In several cases, we contacted the authors of the primary studies for more detailed information and raw data.

Disorganized attachment classifications (D) are assigned in addition to the traditional organized attachment classifications (A, B, and C). In 20 studies on 25 samples ( $n=$ 1,219) disorganized attachment appeared to be compatible with each of the three organized patterns: in $34 \%$ of the cases disorganized attachment was accompanied with a secondary classification of avoidance (D/A); in $14 \%$ of the cases it was a combination of disorganization with a secondary secure pattern $(\mathrm{D} / \mathrm{B})$; and in $46 \%$ of the cases disorganization was combined with ambivalence $(\mathrm{D} / \mathrm{C})$. Some researchers have suggested that disorganized infants with an alternate $\mathrm{A}$ or $\mathrm{C}$ classification may function differently from disorganized infants whose secondary, organized attachment strategy is secure (Lyons-Ruth, Easterbrooks, \& Cibelli, 1997), whereas others have emphasized the similarity of disorganized attachment regardless of secondary classification (Spangler \& Grossmann, 1993). Unfortunately, we were not able to test this issue meta-analytically because sufficiently detailed data on secondary classifications was absent in most papers. Therefore, we focused on the general contrast between disorganized attachment (regardless of secondary classification) and the organized attachment categories. 


\section{Categorical data analysis}

Following our earlier papers (Van Ijzendoorn, Goldberg, Kroonenberg, \& Frenkel, 1992; Van Ijzendoorn \& Kroonenberg, 1988), the samples were cast in a contingency table with the standard probability distribution, based on the nonclinical North American samples of younger infants, as one of the two marginal distributions and frequencies of $\mathrm{A}, \mathrm{B}, \mathrm{C}$, and $D$ classifications over the separate samples as the other (Table 1). In the first place, a $\chi^{2}$ goodness-of-fit statistic was computed, using the program Multinom (Kroonenberg, 1998). This allowed an omnibus test of the deviation of the sample distribution from the standard distribution. The program also computes standardized residuals for each cell of Table 1, which were used to assess which cells mainly accounted for the deviance (Bishop, Fienberg, \& Holland, 1975). A large standardized residual indicates that the observed cell frequency is considerably larger or, if the sign is negative, smaller than expected from the marginals. Bonferroni-like corrections of the standard $\alpha$ level of .05 insured protection from capitalizing on chance significance.

\section{Calculation of effect sizes}

In the meta-analysis Pearson's product-moment correlation coefficient $(r)$ was used as the effect size estimate. If a study reported means and standard deviations, one-directional $t$ values were computed and transformed into $r$ using Schwarzer's (1989) algorithms. If no means and standard deviations were available, the reported test statistics ( $t$, $F$, or $\chi^{2}$ ) or the one directional $p$ value were transformed into $r$ with Mullen's (1989) computer program. We applied conservative estimation procedures if a study only reported "no significant effect" or "a significant effect" (Mullen, 1989).

To compute combined effect sizes each correlation coefficient was transformed to a Fisher's $Z$ (Mullen, 1989) and, in combining the effect sizes, individual effect sizes were weighted by sample size (Mullen, 1989; Rosenthal, 1991). Because the extremely large
NICHD study on daycare was included in several meta-analyses (NICHD Early Child Care Research Network, 1997), we also checked whether weighting effect sizes by unit 1 led to different conclusions. This was not the case. A homogeneity test was performed to determine to what extent effect sizes were constant across studies and had a common population effect size (Hedges \& Olkin, 1985; Rosenthal, 1991). Regardless of whether this homogeneity test is significant, Johnson, Mullen, and Salas (1995) suggest to check for significant moderator variables that may partly account for the variation across studies (see also Rosenthal, 1995). To determine whether a study characteristic explained variation in effect sizes, Rosenthal's method of focused comparison of combined effect sizes was used (Mullen, 1989). In case of dichotomous moderators, blocking was used to test their influence (Mullen, 1989). Different sets of moderators were used in different meta-analyses but in all analyses publication year, sample size, age of participants, and their socioeconomic status were included.

\section{Results}

\section{Frequency of disorganized attachment in nonclinical and clinical groups}

The percentage of disorganized infant attachment in "normal," middle class, nonclinical groups in North America (the "standard" distribution) was $15 \%$, with $15 \% \mathrm{~A}, 62 \% \mathrm{~B}$, and $9 \% \mathrm{C}(n=2,104)$. In older children the same percentage $\mathrm{D}$ was found $(15 \% ; n=492)$. The infant $\mathrm{A}, \mathrm{B}, \mathrm{C}, \mathrm{D}$ distributions from middle class and lower class samples differed significantly, $\chi^{2}=62.12 ; p<.001 ; n=2,690$. In low SES samples $(n=586)$, the percentage of disorganized infants was $25 \%$, which was significantly higher than in the middle class samples, $z=6.45$. The effect size for the $D$ versus non-D contrast was $r=.11$. When only the Main and Solomon (1990) classifications were included, the percentage of $D$ in lower class samples increased to $34 \%(n=338)$. The standard distribution also differed significantly from the distribution in other Western 
Table 1. Distributions of $A, B, C$, and $D$ classifications in normal and clinical samples

\begin{tabular}{|c|c|c|c|c|c|c|c|c|c|}
\hline \multirow[b]{2}{*}{ Study } & \multicolumn{4}{|c|}{ Distribution } & \multirow[b]{2}{*}{$n_{d}$} & \multicolumn{4}{|c|}{ Standaidized Resıduals } \\
\hline & A & B & $\mathrm{C}$ & $\mathrm{D}$ & & A & B & $\mathrm{C}$ & $\mathrm{D}$ \\
\hline
\end{tabular}

NM Normal U S samples, age $<24$ months

\begin{tabular}{|c|c|c|c|c|c|c|c|c|c|}
\hline $\mathrm{NM}^{a}{ }^{a}$ Man (pers commun, 1990) & 38 & 71 & 9 & 23 & $141^{*}$ & 415 & -183 & -097 & 049 \\
\hline NM2 ${ }^{a}$ Goldberg et al (1995) & 6 & 34 & 5 & 6 & 51 & $-\overline{057}$ & 046 & 029 & -058 \\
\hline NM3 $^{a}$ Pederson et al (1996) & 11 & 27 & 8 & 9 & 55 & 104 & -122 & 154 & 030 \\
\hline NM4 ${ }^{a}$ Ward et al (1993) & 7 & 18 & 1 & 2 & 28 & 143 & 017 & -092 & -107 \\
\hline NM5 $^{a}$ Speltz et al (1997) & 10 & 43 & 4 & 7 & 64 & 018 & 057 & -067 & -083 \\
\hline NM6 ${ }^{a}$ Benot \& ParkeI (1994) & 4 & 52 & 7 & 25 & $88^{\circ}$ & -257 & -033 & -023 & 352 \\
\hline NM7 $7^{a}$ Pipp-Siegel et al (1995) & 13 & 76 & 16 & 8 & 113 & -095 & 079 & 214 & -223 \\
\hline NM8“ Fish \& Stifter (1995) & 9 & 45 & 2 & 6 & 62 & -006 & 112 & -148 & -108 \\
\hline NM9 $^{a}$ Tet et al (1995) & 2 & 14 & 2 & 2 & 20 & -056 & 047 & 021 & -057 \\
\hline NM10 ${ }^{a}$ NICHD (1997) & 161 & 711 & 102 & 177 & 1,151 & -150 & 003 & -055 & 109 \\
\hline NM11 ${ }^{a}$ Howes \& Hamilton (1992) & 23 & 66 & 14 & 6 & 109 & 183 & -017 & 159 & -262 \\
\hline \multicolumn{10}{|l|}{ NM12 ${ }^{a}$ Ainsworth \& E1chberg } \\
\hline (1991) & 6 & 23 & 1 & 15 & 45 & -026 & -093 & -149 & 33 \\
\hline NM13 $^{a}$ Scholmerich et al (1997) & 1 & 26 & 5 & 4 & 36 & -189 & 082 & 109 & -05 \\
\hline \multicolumn{10}{|l|}{ NM14“ Lederberg \& Mobley } \\
\hline$(1990)$ & 11 & 24 & 2 & 4 & 41 & 206 & -027 & -083 & -086 \\
\hline NM15 ${ }^{a}$ Beeghly et al (1997) & 9 & 69 & 4 & 18 & 100 & -156 & 097 & -164 & 087 \\
\hline (standard) & 311 & 99 & 182 & 312 & 2,104 & & & & \\
\hline
\end{tabular}

Normal other

NMO Normal U S samples, age $\geq 24$ months
NMO1 Main \& Cassidy (1988)
NMO2 Solomon et al (1995)
NMO3 Frankel \& Harmon (1996)
NMO4 DeMulder \& Radke- Yarrow (1991)
NMO5 Marcovitch et al (1997)
NMO6 Cohn (1990)
NMO7 Speltz et al (1990)
NMO8 Greenberg et al (1991)
NMO9 Moss et al (1998)
NMO10 Chatoor \& Ganıban (1998)

Total normal US, age $\geq 24$ months $^{b}$

CW Normal Western

CW1 Harrison \& Ungerer (1996)

CW2 Jacobsen \& Hoffmann (1997)

CW3 Jacobsen et al (1994)

CW4 Ammanit \& Speranza (1995)

CW5 Spangler et al (1996)

CW6 Schuengel et al (1999)

CW7 Bakermans-Kranenburg \& Van Ijzendoorn (1997)

CW8 Steele et al (1996a)

CW9 Steele et al (1996a) (fathers)

CW10 Murray (1992)

$\begin{array}{rrrrrrrrr}12 & 18 & 6 & 14 & 50 & 170 & -232 & 081 & 242 \\ 9 & 11 & 14 & 8 & 42^{+} & 112 & -293 & \underline{544} & 071 \\ 7 & 19 & 4 & 2 & 32 & 104 & -017 & 074 & -126 \\ & & & & & & & & \\ 8 & 26 & 3 & 8 & 45 & 052 & -034 & -045 & 051 \\ 17 & 16 & 1 & 4 & 38^{*} & \underline{4} 80 & -154 & -126 & -069 \\ 12 & 50 & 5 & 13 & 80 & 005 & 009 & -073 & 033 \\ 2 & 18 & 2 & 3 & 25 & -088 & 065 & -011 & -037 \\ 4 & 18 & 0 & 3 & 25 & 016 & 065 & -147 & -037 \\ 20 & 71 & 12 & 18 & 121 & 050 & -043 & 047 & 001 \\ & & & & & & & & \\ 3 & 28 & 3 & 0 & 34 & -090 & 153 & 003 & -225 \\ 94 & 275 & 50 & 73 & 492 & 249 & -165 & 114 & 000 \\ & & & & & & & & \\ 12 & 85 & 35 & 13 & 145^{*} & -204 & -048 & 634 & -183 \\ & & & & & & & & \\ 35 & 41 & 5 & 27 & 108^{*} & \underline{476} & -314 & -142 & 274 \\ 9 & 17 & 2 & 7 & 35 & 168 & -099 & -059 & 079 \\ & & & & & & & & \\ 18 & 17 & 0 & 15 & 50^{*} & \underline{390} & -250 & -208 & 279 \\ 27 & 37 & 6 & 18 & 88^{*} & \underline{3} 88 & -235 & -058 & 137 \\ 4 & 45 & 10 & 26 & 85^{*} & -242 & -103 & 098 & \underline{377} \\ & 37 & 23 & 18 & 83^{*} & -208 & -199 & \underline{5} 90 & 162 \\ 5 & 32 & 5 & 8 & 90 & 321 & -048 & -100 & -146 \\ 25 & 52 & & & & & & & \\ 25 & 61 & 0 & 4 & 90^{*} & 321 & 073 & -279 & -256 \\ 9 & 29 & 0 & 0 & 38 & 143 & 114 & -181 & -237\end{array}$


CW11 Meins et al (1998)

CW12 Raub et al (in press)

Total normal Western"

Total normal other

CC Non-Western

CC1 True (1994)

CC2 Zevalkınk (1997)

CC3 Valenzuela (1990)

CC4 Sagı et al (1994)

CC5 Scholmerich et al (1997)

(Central-American immigrants)

Total non-Western ${ }^{b}$

Low SES

NL Low SES samples, age $<24$ months

NL1 Vondra et al (1997)

NL2 Dawson et al (1992)

NL3 Callson (1998)

NL4 Lyons-Ruth et al (1997)

NL5 Carlson et al (1989)

NL6 Crittenden (1985)

NL7 Fish \& Fish (1998)

Total low SES samples, age $<24$ months $^{b}$

NLO Low SES samples, age $\geq 24$ months

NLO1 Moore et al (1997)

NLO2 Crittenden (1988)

Total low SES samples, age $\geq 24$ months ${ }^{b}$

Total low SES

Child problems

P Prematurity

P1 Goldberg et al (1989)

P2 Rodning et al (1989)

P3 Cox (1995)

Total premature ${ }^{c}$

PH Physical problems

PH1 Goldberg et al (1995)

PH2 Goldberg et al (1995)

PH4 Speltz et al (1997) (CLP)

PH5 Speltz et al (1997) (CF)

PH6 Lederberg \& Mobley

(1990) (hearıng impaired)

Total physical problems ${ }^{c}$

Total child problems ${ }^{d}$

MP Neurological abnormality

MP1 Vaughn et al (1994) (Down synd )

MP2 Capps et al (1994) (aut1sm)

MP3 Willemsen et al (1997) (autısm)

MP4 Sierra (1989) (CP)

$\begin{array}{rrrrcrrrr}6 & 19 & 4 & 4 & 33 & 051 & -030 & 068 & -040 \\ 11 & 29 & 5 & 30 & 75^{*} & -003 & -254 & -058 & \underline{566} \\ 186 & 469 & 95 & 170 & 920^{*} & \underline{429} & -415 & 173 & 287 \\ 280 & 744 & 145 & 243 & 1,412 & & & & \end{array}$

$\begin{array}{rrrrrrrrr}0 & 18 & 2 & 6 & 26 & -196 & 049 & -017 & 109 \\ 3 & 24 & 9 & 10 & 46 & -146 & -083 & 252 & 122 \\ 9 & 20 & 9 & 2 & 40 & 127 & -094 & 298 & -161 \\ 0 & 21 & 9 & 18 & 48^{*} & -266 & -159 & 238 & \underline{408} \\ 3 & 22 & 7 & 6 & 38 & -110 & -030 & 205 & 015 \\ 15 & 105 & 36 & 42 & 198^{*} & -264 & -156 & \underline{456} & 233\end{array}$

$\begin{array}{rrrrcrrrr}40 & 117 & 35 & 31 & 223^{*} & 123 & -176 & 358 & -036 \\ 1 & 17 & 0 & 8 & 26 & -145 & 024 & -150 & 211 \\ 18 & 47 & 14 & 43 & 122^{*} & -001 & -326 & 106 & \underline{586} \\ 15 & 27 & 0 & 34 & 76^{*} & 112 & -291 & -256 & \underline{677} \\ 2 & 11 & 4 & 4 & 21 & -063 & -055 & 162 & 050 \\ 6 & 16 & 3 & 0 & 25 & 120 & 014 & 057 & -193 \\ 15 & 47 & 4 & 27 & 93^{*} & 034 & -137 & -143 & 356 \\ & & & & & & & & \\ 97 & 282 & 60 & 147 & 586^{*} & 112 & -\underline{420} & 131 & \underline{645} \\ & & & & & & & & \\ 21 & 59 & 56 & 18 & 154^{*} & -037 & -\underline{370} & \underline{1169} & -101 \\ 18 & 25 & 4 & 4 & 51^{*} & 381 & -116 & -020 & -130 \\ & & & & & & & & \\ 39 & 84 & 60 & 22 & 205^{*} & 158 & -378 & \underline{1004} & -152 \\ 136 & 366 & 120 & 169 & 791 & & & & \end{array}$

$\begin{array}{rrrrrrrrr}7 & 40 & 2 & 15 & 64 & -080 & 008 & -150 & 179 \\ 2 & 24 & 3 & 12 & 41 & -165 & -026 & -029 & 240 \\ 10 & 32 & 4 & 12 & 58 & 049 & -064 & -045 & 116 \\ 19 & 96 & 9 & 39 & 163 * & -104 & -046 & -136 & 302 \\ & & & & & & & & \\ 8 & 17 & 2 & 13 & 40 & 086 & -155 & -078 & 290 \\ 12 & 23 & 5 & 14 & 54 & 142 & -179 & 015 & 212 \\ 3 & 18 & 2 & 1 & 24 & -029 & 083 & -005 & -136 \\ 5 & 16 & 6 & 0 & 27 & 051 & -016 & 240 & -200 \\ & & & & & & & & \\ 6 & 22 & 3 & 10 & 41 & -002 & -066 & -029 & 159 \\ 34 & 96 & 18 & 38 & 186 & 124 & -176 & 048 & 198 \\ 53 & 192 & 27 & 77 & 349 * & 020 & -160 & -058 & 351\end{array}$

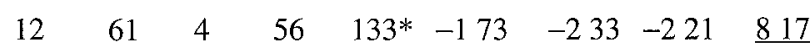

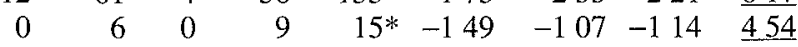

$\begin{array}{llllllllll}4 & 14 & 3 & 10 & 31 & -027 & -117 & 019 & 252\end{array}$

$\begin{array}{lllllllll}11 & 11 & 2 & 5 & 29 & 324 & -163 & -032 & 034\end{array}$ 
Table 1. Contmued

\begin{tabular}{|c|c|c|c|c|c|c|c|c|c|}
\hline \multirow[b]{2}{*}{ Study } & \multicolumn{4}{|c|}{ Distribution } & \multirow[b]{2}{*}{$n_{d}$} & \multicolumn{4}{|c|}{ Standardızed Resıduals } \\
\hline & A & B & $\mathrm{C}$ & $\mathrm{D}$ & & A & B & $\mathrm{C}$ & $\mathrm{D}$ \\
\hline \multicolumn{10}{|l|}{ MP Neurological abnormality (cont' $d$ ) } \\
\hline MP5 Hunt et al (1997) (neuro) & 5 & 9 & 3 & 3 & 20 & 119 & -095 & 097 & 002 \\
\hline MP6 Hunt et al (1997) (cranıal) & 2 & 13 & 1 & 7 & 20 & -056 & 019 & -056 & 060 \\
\hline Total neurological abnormalıty ${ }^{c}$ & 34 & 114 & 13 & 87 & $248^{+}$ & -044 & $-\underline{316}$ & -182 & $\underline{828}$ \\
\hline \multicolumn{10}{|l|}{$\begin{array}{l}\text { Maternal problems } \\
\text { M Maltreatment }\end{array}$} \\
\hline M1 Barnett et al (1997) & 0 & 3 & 0 & 19 & $22^{+}$ & -180 & -287 & -138 & 871 \\
\hline M2 Crittenden (1985) & 7 & 0 & 5 & 9 & $21^{k}$ & 221 & -360 & 236 & 334 \\
\hline M3 Crittenden (1988) & 25 & 7 & 7 & 33 & $72^{+}$ & $\underline{440}$ & $-\underline{562}$ & 031 & 683 \\
\hline M4 Valenzuela (1990) & 13 & 3 & 12 & 13 & $41^{+}$ & $\overline{282}$ & $-\overline{443}$ & 449 & 28 \\
\hline M5 Lyons-Ruth et al (1990) & 2 & 2 & 0 & 5 & 9 & 058 & $-\overline{151}$ & -088 & 317 \\
\hline Total maltreatment ${ }^{c}$ & 47 & 15 & 24 & 79 & $165^{+}$ & $\underline{458}$ & -861 & 257 & 1102 \\
\hline AM Teen mothers & & & & & & & & & \\
\hline AM1 Ward \& Carlson (1995) & 26 & 34 & 3 & 14 & $77^{*}$ & 433 & -196 & -142 & 076 \\
\hline AM2 Broussard (1995) & 13 & 9 & 4 & 12 & $38+$ & 312 & -299 & 039 & 2 \\
\hline AM3 Sp1eker \& Bensley (1994) & 30 & 66 & 3 & 34 & $133^{*}$ & 233 & -178 & -251 & 32 \\
\hline AM4 Hubbs-Tait et al (1996) & 24 & 4 & 0 & 6 & $34^{*}$ & $\underline{846}$ & -371 & -171 & 043 \\
\hline Total teen mothers & 93 & 113 & 10 & 66 & $282^{*}$ & $\underline{795}$ & -463 & -291 & 374 \\
\hline
\end{tabular}

Drug/alcohol abuse

DA1 O'Connor et al (1987, 1992)

DA2 Rodning et al (1989)

DA3 Rodning et al (1991)

DA4 Claussen et al (1998)

Total drugs/alcohol ${ }^{d}$

DE Depression

DE1 DeMulder \& Radke-

Yarrow (1991) (bipolar)

DE2 DeMulder \& Radke-

Yarrow (1991) (unipolar)

DE3 Murray (1992) (postnatal)

DE4 Murray (1992) (prenatal)

DE5 Murray (1992) (pre + postnatal)

DE6 Tet1 et al (1995) (young)

DE7 Tet1 et al (1995) (older)

DE8 Frankel \& Harmon (1996)

DE9 Seifer, Sameroff, et al

(1996) (depr + other disorders)

$\begin{array}{rrrrrrrrr}6 & 22 & 2 & 16 & 46 & -031 & -120 & -099 & 351 \\ 3 & 7 & 1 & 7 & 18 & 021 & -123 & -045 & 265 \\ 6 & 4 & 10 & 15 & 35^{*} & 036 & -\underline{379} & \underline{401} & \underline{431} \\ 6 & 5 & 10 & 24 & 45^{*} & -025 & \underline{-432} & 310 & \underline{671} \\ 21 & 38 & 23 & 62 & 144^{*} & -006 & -\underline{540} & 299 & \underline{800}\end{array}$

Total depression ${ }^{d}$

Total maternal problems ${ }^{b}$

MI Other problems

MI1 DasEiden \& Lenard (1996) (father alcoholic)

MI2 Ward et al (1993) (FTT)

MI3 Marcovitch et al (1997) (adoption)

MI4 DeKlyen (1996) (ODD)

MI5 Speltz et al (1990) (ODD)

MI6 Manassis et al (1994) (anxiety disorder)

$\begin{array}{rrrrlrrrr}2 & 8 & 2 & 12 & 24^{*} & -082 & -177 & -005 & \underline{447} \\ 6 & 25 & 2 & 10 & 43 & -014 & -030 & -089 & 143 \\ 16 & 15 & 2 & 2 & 35^{*} & \underline{476} & -142 & -059 & -140 \\ 6 & 4 & 0 & 0 & 10^{*} & \underline{372} & -087 & -093 & -122 \\ 13 & 6 & 0 & 2 & 21^{*} & \underline{562} & -193 & -135 & -063 \\ 5 & 6 & 7 & 12 & 30^{*} & 027 & -291 & 273 & 358 \\ 6 & 4 & 12 & 9 & 31^{*} & 066 & -346 & \underline{569} & 205 \\ 6 & 21 & 3 & 0 & 30 & 074 & 058 & 025 & -211 \\ 10 & 51 & 31 & 24 & 116^{*} & -173 & -244 & \underline{662} & 164 \\ 70 & 140 & 59 & 71 & 340^{*} & 278 & -\underline{483} & \underline{546} & 290 \\ 231 & 306 & 116 & 278 & 931^{*} & \underline{796} & -\underline{1121} & \underline{395} & \underline{1191}\end{array}$

$\begin{array}{rrrrrrrrr}11 & 8 & 1 & 3 & 23^{*} & \underline{412} & -165 & -070 & -022 \\ 5 & 9 & 0 & 12 & 26^{*} & 059 & -176 & -150 & \underline{415} \\ 0 & 15 & 11 & 18 & 44^{*} & -255 & -233 & \underline{369} & \underline{449} \\ 6 & 5 & 2 & 12 & 25^{*} & 120 & -266 & -011 & \underline{431} \\ 3 & 4 & 2 & 16 & 2^{*} & -036 & -291 & -011 & \underline{638} \\ 2 & 4 & 1 & 13 & 20^{*} & -056 & -238 & -056 & \underline{583}\end{array}$


MI7. Willemsen et al (1997) (language delay)

MI8- Chatoor \& Ganıban (1998) (infantıle anorexia)

MI9. Chatoor \& Ganıban (1998) (picky eaters)

Total other problems

Grand total

$\begin{array}{rrrrrrrrr}0 & 14 & 1 & 3 & 18 & -163 & 0.87 & -0.45 & 0.20 \\ 4 & 20 & 7 & 2 & 33 & -0.40 & -008 & 2.45 & -1.31 \\ 3 & 30 & 1 & 0 & 34 & -090 & 1.97 & -1.13 & -2.25 \\ 34 & 109 & 26 & 79 & 248 & & & & \end{array}$

$1,094 \quad 3,235 \quad 665 \quad 1,287 \quad 6,281$

Note Each sample was compared with the standard distribution Two-talled Bonferronı level was 0006 for the sample distributions (critical $\chi^{2}$ goodness of fit $=1627$ ) Two-taled Bonferrom level was 00016 for the standardized residuals in the cells (critical $z=365$ )

'These samples weie compared with the rest of the standard distribution Two-talled Bonferronı level was 0034 for the sample distributions (critical $\chi^{2}$ goodness of fit $=1455$ ) Two-tailed Bonferron level was 0011 for the standard1zed residuals (critical $z=306$ )

${ }^{b}$ These totals were compared with standard distribution Two-talled Bonferroni level was 01 for the distributions (critical $\chi^{2}$ goodness of $\mathrm{fit}=1134$ ) Two-tarled Bonferron level was 0025 for the standardized residuals (critical $z=$ 281)

'These totals were compated with the standard distribution Two-talled Bonferron level was 007 for the distributions (critical $\chi^{2}$ goodness of fit $=1209$ ) Two-tailed Bonferron level was 0018 for the standardized residuals (crit1cal $z=2$ 92)

"These totals were compared with standard distribution Two-taled Bonferronı level was 025 for the distributions (critical $\chi^{2}$ goodness of $f_{1 t}=935$ ) Two-tailed Bonferron 1 level was 0063 for the standardized residuals (critical $z=$ 249)

*Distributions that deviate significantly from the standard distribution Cells within these distributions that deviate significantly are underlined

countries, $\chi^{2}=46.90 ; p<.001 ; n=3,024$, but the percentage of disorganized attachment classifications did not differ $(18 \% ; z=2.87)$. Instead, the percentage of avoidant attachments was significantly higher $(z=4.29)$ and that of secure attachments significantly lower $(z=-4.15)$ than in the standard North-American distribution. When only the Main and Solomon classifications were included, the percentage of $\mathrm{D}$ in other Western countries was $17 \%(N=812)$. Compared to the standard distribution, the non-Western cultures appeared to differ, $\chi^{2}=35.62 ; p<.001 ; n=$ 2,302. The non-Western distribution showed more ambivalent $(z=4.56)$ attachments (see Table 1), but a similar percentage of disorgan1zed attachments (21\%). All non-Western studies were based on the Main and Solomon (1990) coding system for disorganized attachment.

In most clinical groups the percentages of disorganized children were higher than in the standard distribution. In samples with neurological abnormalıties $(n=248)$ such as cerebral palsy (Sierra, 1989), autism (Capps, Sıgman, \& Mundy, 1994; Willemsen, Bakermans-Kranenburg, Buitelaar, Van Ijzendoom, \& Van Engeland, 1998), and Down's syn- drome (Vaughn et al., 1994), the percentage of disorganized children was $35 \%(z=8.28)$. In groups of mothers with alcohol or drugs abuse $(n=144)$, the percentage of disorganized infants was $43 \%, z=8.80$. In groups of maltreating parents $(n=165), 48 \%$ of the children were found to be disorganized, $z=$ 11.02. This percentage of disorganized maltreated children was higher when only Main and Solomon (1990) codings were used (77\%; $n=31$ ). It was remarkable that in groups with depressed parents $(n=340)$ the percentage of disorganized children was only $21 \%, z=2.90$; n.s. With the Main and Solomon classifications the percentage of disorganızed children of depressed mothers was 19\% $(n=212)$. Children with severe physical problems $(n=$ 186; e.g., congenital heart disease, Goldberg, Gotowiec, \& Simmons, 1995; cleft lip and palate, Speltz, Endriga, Fisher, \& Mason, 1997) did not develop significantly more often disorganized attachment either $(20 \% ; z=$ 1.98, n.s.). In samples with teen mothers $(n=$ 282), the percentage of disorganized children was elevated compared to the standard distribution $(23 \% ; z=3.74)$ but this percentage was similar to the percentage of disorganized children found in low SES samples. Exclusion 
Table 2. Stability of disorganized attachment across time

\begin{tabular}{|c|c|c|c|c|c|c|c|}
\hline \multirow[b]{2}{*}{ Study } & \multirow[b]{2}{*}{$n$} & \multirow[b]{2}{*}{ SES } & \multirow[b]{2}{*}{$\begin{array}{c}\text { Age } \\
\text { (Time 1) }\end{array}$} & \multirow{2}{*}{$\begin{array}{c}\text { Lag } \\
\text { (months) }\end{array}$} & \multicolumn{3}{|c|}{ Stability } \\
\hline & & & & & $\%$ & $r$ & $\chi^{2}$ \\
\hline 1. Main \& Cassidy (1988), mothers & 32 & Middle & 12 & 60 & 87 & .73 & 17.11 \\
\hline 2. Main \& Cassidy (1988), fathers & 33 & Middle & 18 & 54 & 85 & .25 & 2.01 \\
\hline 3. Main \& Cassidy (1988) & 50 & Middle & 72 & 1 & 76 & .38 & 7.21 \\
\hline 4. Wartner et al. (1994) & 39 & Diverse & 12 & 60 & 82 & .59 & 13.54 \\
\hline 5. Lyons-Ruth et al. (1991) & 46 & Low & 12 & 6 & 50 & -.12 & 0.67 \\
\hline \multicolumn{8}{|l|}{ 6. Barnett et al. (1997), } \\
\hline comparisons & 21 & Low & 12 & 6 & 81 & .53 & 5.97 \\
\hline 7. Barnett et al. (1997), maltreated & 18 & Low & 12 & 6 & 67 & .25 & 1.17 \\
\hline 8. Vondra et al. (1997) & 195 & Low & 12 & 6 & 79 & .31 & 18.91 \\
\hline \multicolumn{8}{|l|}{ 9. Bakermans-Kranenburg \& Van } \\
\hline Ijzendoorn (1997) & 81 & Middle & 12 & 2 & 80 & .38 & 11.62 \\
\hline 10. Carlson (1998) & 48 & Low & 12 & 6 & 79 & .59 & 16.80 \\
\hline 11. Milentijevic et al. (1995) & 86 & Low & 12 & 30 & 69 & .16 & 2.34 \\
\hline 12. Rauh et al. (in press) & 72 & Middle & 12 & 9 & 69 & .36 & 9.59 \\
\hline 13. Jacobsen et al. (1997) & 32 & Middle & 18 & 54 & 72 & .36 & 4.23 \\
\hline 14. Steele et al. (1996b) & 87 & Middle & 12 & 48 & 87 & .21 & 3.67 \\
\hline Combined & $N=840$ & & & & & $r=.34$ & \\
\hline
\end{tabular}

of the Hubbs-Tait et al. (1996) sample in which the Main and Solomon (1990) system was not used yielded a similar outcome.

\section{Stability of disorganized attachment}

In 14 samples including $n=840$ participants the stability of disorganized attachment across 1-60 months (average time lag was 25 months) was $r=.34$ (see Table 2). The effect sizes were heterogeneous, $\chi^{2}(13)=34.62, p<.001$, and it was not possible to create homogeneous sets of studies on the basis of moderator analyses. In samples with middle class or diverse socioeconomic backgrounds, stability was $r=$ $.39(n=426 ; p<.001)$. In samples with low socioeconomic status, stability was $r=.29$ $(n=414 ; p<.001)$. The difference in stability was not significant. Time lag between the two measurements of disorganization was not significantly associated with stability. The long-term stability of disorganization was remarkably strong. If we consider controlling behavior a sequela of disorganized infant attachment, the effect size for the association between disorganized infant attachment and later controlling attachment behavior in the pertinent studies (Jacobsen, Huss, Fendrich, Kruesi, \& Ziegenhain, 1997; Main \& Cassidy,
1988; Steele, Steele, \& Fonagy, 1996b; Wartner, Grossmann, Fremmer-Bombik, \& Suess, $1994)$ amounts to $r=.40(n=223 ; p<.001)$. The short-term stability of disorganized attachment as assessed twice with the Main and Solomon (1990) coding system was $r=.35$ $(n=286 ; p<.001)$.

\section{Constitutional and temperamental correlates of disorganized attachment}

Temperament. In 13 samples, including 2,028 participants, the association between disorganized attachment and constitutional and temperamental variables was examined (see Table 3). The combined effect size across these studies was $r=.0008$ (n.s.), and this set of outcomes was homogeneous. When only the Main and Solomon (1990) classifications were included the combined effect size of the 12 studies was $r=.005$ (n.s.). In the nine studies on difficult temperament the association with disorganized attachment was only $r=.02$ (n.s.; $n=1,790$ ). All studies used the Main and Solomon (1990) coding system. There is no reason to assume that disorganized attachment is the consequence of the infant's difficult temperament. In the four studies on medi- 
Table 3. Constitutional factors and infant attachment disorgantzation

\begin{tabular}{|c|c|c|c|c|c|c|}
\hline Study & $n$ & $\begin{array}{c}\text { Age } \\
\text { (months) }\end{array}$ & SES & Constitutional Factor & Statistic & $\begin{array}{l}\text { Effect } \\
\text { Size }(r)\end{array}$ \\
\hline 1 NICHD (1997) & 1,138 & 15 & Diverse & Difficult temp & $t=053$ & 02 \\
\hline 2 Shaw et al (1996) & 83 & 18 & Low & Difficult temp & $r=-02$ & -02 \\
\hline 3 Barnett et al (1997) & 44 & 12 & Low & Reactivity (temp ) & $x^{2}=159$ & 19 \\
\hline 4 Seifer, Schiller, et al (1996) & 49 & 12 & Middle & Difficult temp & $p=50$ & 00 \\
\hline 5 Spangler et al (1996) & 88 & 12 & Diverse & NBAS (temp) & $r=19$ & 19 \\
\hline 6 Lyons-Ruth et al (1997) & 69 & 18 & Low & Distress/anger (temp ) & $r=13$ & 13 \\
\hline $7 \operatorname{Cox}(1995)$ & 58 & 19 & Low & Brain insult & $t=129$ & 17 \\
\hline 8 Greenberg et al (1991) & 19 & 52 & Middle & Medıcal problems & $\chi^{2}=277$ & -38 \\
\hline 9 Zevalkınk (1997) & 46 & 21 & Low & Health & $t=-154$ & -23 \\
\hline 10 Speltz et al (1997) & 115 & 12 & Mıddle & Cleft palate & $\chi^{2}=353$ & -18 \\
\hline 11 Schuengel et al (1999) & 85 & 12 & Middle & Reactivity (temp) & $t=099$ & -11 \\
\hline \multicolumn{7}{|l|}{12 Bakermans \& Van } \\
\hline Ijzendoorn (1997) & 83 & 12 & Middle & Difficult temp & $r=-09$ & -09 \\
\hline 13 Carlson (1998) & 151 & 15 & Low & Difficult temp & $r=-02$ & -02 \\
\hline Combined & $N=2,028$ & & & & $r=0008$ & \\
\hline
\end{tabular}

cal or health problems the combined effect size was $r=-12$ (n s ), indicating that disorganızed attachment is not due to sometımes severe physical problems (brain injury, cleft palate) In the studies using the Main and Solomon (1990) system, the effect size was $r=$ $-10$

Sex Boys have been suggested to be more liable to develop disorganized attachment behaviors than girls (Lyons-Ruth et al , 1997) as they seem to be more vulnerable to env1ronmental risks in general (Benenson, 1996) In Table 4, 11 studies on sex and disorganized attachment involving $n=1,858$ participants have been listed The combined effect size across these studies was $r=-01$ (n s) Excluding the study using the controlling attachment category for older children (Cohn, 1990), we found a simtlar absence of an assoclation between sex and disorganization The set of study outcomes was heterogeneous, however, $\chi^{2}(10)=2061, p=02$ In particular the rather small study by Carlson et al (1989) on non-maltreated subjects showed an outlying effect size of $r=51$ Without this study the set of studies was homogeneous

Concordance of infant-mother/infant-father disorganized attachment If disorganized attachment is relationshıp-specific the organısmic or constitutional explanation becomes less plausible In three studies (Hesse \& Marn, in press, Owen \& Cox, 1997, Steele, Steele, \& Fonagy, 1996a) the association between disorganized attachment behavior in the presence of the mother and the father was examined Steele et al (1996a) found an effect size of $r=07$ in a sample of $n=90$ part1cipants Owen and Cox (1997) found a larger effect size of $r=28$ in a somewhat smaller sample of 33 participants Hesse and Main (in press) found an effect size of $r=08$ in a large sample of $n=151$ The combined effect size was $r=10$ (n s) which is somewhat smaller than the concordance of the organized attachment classifications for infant-mother and infant-father relationships $(r=17$, see Van Ijzendoorn \& De Wolff, 1997)

\section{Precursors of disorganized attachment}

Maltreatment Child maltreatment has been considered to be one of the most important causes of disorganized attachment (Crittenden \& Answorth, 1989, George, 1996) In one of the first studies on disorganized attachment as assessed with the Main and Solomon (1990) coding system, Cicchetti and his colleagues (Barnett, Ganiban, \& Cicchett1, 1997, Beeghly \& Cicchett1, 1994, Carlson et al, 1989, Cicchett1 \& Barnett, 1991) found more than $80 \%$ of the maltreated children to be disorganized Unfortunately, the number of repl1- 
Table 4. Sex differences in disorganized child attachment

\begin{tabular}{|c|c|c|c|c|c|c|c|}
\hline Study & $n$ & $\begin{array}{c}\text { Age } \\
\text { (months) }\end{array}$ & SES & Statıstic & $p_{1}$ & $\begin{array}{c}\text { Effect } \\
\text { Size }(r)\end{array}$ & $\begin{array}{c}\text { Boys } \\
\text { More } \\
\text { D }\end{array}$ \\
\hline 1 NICHD (1997) & 1,153 & 15 & Diverse & $\chi^{2}=294$ & 09 & -05 & No \\
\hline 2 Lyons-Ruth et al (1997) & 70 & 18 & Low & $F(1,69)=850$ & $<05$ & 33 & Yes \\
\hline 3 Broussard (1995) & 38 & 14 & Low & $\chi^{2}=005$ & $>05$ & -05 & No \\
\hline $\begin{array}{l}4 \text { Carlson et al (1989), } \\
\text { maltreated }\end{array}$ & 22 & 13 & Low & $\chi^{2}=122$ & 28 & 24 & Yes \\
\hline 5 Carlson et al (1989), & & & & & 20 & 24 & \\
\hline nonmaltreated & 21 & 13 & Low & $\chi^{2}=544$ & 02 & 51 & Yes \\
\hline 6 Cohn (1990) & 80 & 74 & Middle & $\chi^{2}=087$ & 38 & -10 & No \\
\hline 7 Hubbs-Tait et al (1994) & 44 & 13 & Low & & $>05$ & -13 & No \\
\hline 8 Harrison \& Ungerer (1996) & 145 & 12 & Middle & $\chi^{2}=028$ & 77 & -04 & No \\
\hline 9 Bakermans \& Van & & & & & & & \\
\hline Ijzendoorn (1997) & 83 & 12 & Middle & $\chi^{2}=050$ & 60 & -08 & No \\
\hline 10 Schuengel et al (1999) & 85 & 12 & Middle & $\chi^{2}=083$ & 24 & 10 & Yes \\
\hline 11 Moss et al (1998) & 117 & 75 & Diverse & $\tilde{\chi}^{2}=0029$ & 86 & 16 & Yes \\
\hline Combined & $N=1,858$ & & & & & $r=-01$ & \\
\hline
\end{tabular}

Table 5. Maltreatment and infant attachment disorganizatıon

\begin{tabular}{|c|c|c|c|c|c|}
\hline Study & $n$ & $\begin{array}{c}\text { Age } \\
\text { (months) }\end{array}$ & $\begin{array}{c}\text { Type of } \\
\text { Maltreatment }\end{array}$ & $\mathrm{D}(\%)$ & $\begin{array}{c}\text { Effect } \\
\text { Size }(\varphi)\end{array}$ \\
\hline 1 Crittenden $(1988)^{a}$ & 46 & $12-24$ & $\begin{array}{c}\text { Abuse/neglect } \\
\text { comparison }\end{array}$ & $\begin{array}{l}9(43) \\
0(0)\end{array}$ & 54 \\
\hline 2 Crittenden $(1988)^{a}$ & 121 & $11-48$ & $\begin{array}{c}\text { Abuse/neglect } \\
\text { comparison }\end{array}$ & $\begin{array}{r}33(45) \\
4(10)\end{array}$ & 40 \\
\hline 3 Lyons-Ruth et al $(1990)^{b}$ & 28 & 18 & $\begin{array}{c}\text { Maltreatment } \\
\text { comparıson }\end{array}$ & $\begin{array}{r}5(55) \\
10(53)\end{array}$ & 03 \\
\hline 4 Barnett et al $(1997)^{c}$ & 44 & 12 & $\begin{array}{l}\text { Abuse } \\
\quad \text { comparison }\end{array}$ & $\begin{array}{r}19(86) \\
6(27)\end{array}$ & 60 \\
\hline 5 Valenzuela $(1990)^{d}$ & 81 & $17-20$ & $\begin{array}{l}\text { Maltreatment } \\
\text { comparison }\end{array}$ & $\begin{array}{r}13(32) \\
2(5)\end{array}$ & 34 \\
\hline Combined & $N=323$ & & & & $\varphi=41$ \\
\hline
\end{tabular}

${ }^{a} \mathrm{~A} / \mathrm{C}$ is considered $\mathrm{D}$

${ }^{b}$ Using the community untreated comparison group, $\varphi=18(n=41)$

${ }^{c}$ Includes Carlson et al (1989) and Beeghly and Cicchett1 (1994)

${ }^{d}$ Valenzuela (1990) discusses the severe parenting disorder of the mothers of undernourished babies

cations of this important study is rather small To our knowledge, only five studies on maltreatment and disorganızed or $\mathrm{A} / \mathrm{C}$ attachment have been published (see Table 5), including $n=323$ participants Across studies, about $48 \%$ of the maltreated subjects appeared to be disorganized, compared to only $17 \%$ of the comparisons All studies documented a strong association between disorganızed attachment and maltreatment, with effect sizes varying between $r=03$ and $r=60$ The combined effect size across the five studies was also impressive $r=41$, and the set of outcomes appeared to be homogeneous When only the Main and Solomon (1990) classifications were included (Barnett et al, 1997, LyonsRuth et al, 1990) the effect size was similar $(r=41)$ It should be noted that Valenzuela (1990) studied undernourıshed Chilean children She considered their parents to suffer 
from a severe parenting disorder (maltreatment in the sense of neglect) as they did not manage to provide their infants with sufficient food even though supplementary feeding programs were available and other mothers in comparable circumstances did protect their infants from malnourishment (Valenzuela, 1990).

Unresolved and early loss or trauma. In a previous meta-analysis, we found that parental unresolved loss or trauma-as assessed in the Adult Attachment Interview (George, Kaplan, \& Main, 1985) — was significantly associated with infant disorganized attachment. Across 10 studies involving $n=548$ participants, the combined effect size was $r=.31$ (Van Ijzendoorn, 1995). Because this metaanalysis was carried out rather recently, it was not repeated and extended here. In the earlier meta-analysis, we did not include studies on reported loss or trauma, regardless of their status as unresolved (Van Ijzendoorn, 1995). Four studies, however, examined the relation between reports of early loss or trauma (before the age of 16 years) and disorganized attachment in the infants (Ainsworth \& Eichberg, 1991; Lyons-Ruth \& Block, 1996; Lyons-Ruth, Repacholi, Mcleod, \& Silva, 1991; Main \& Hesse, 1990). The effect sizes ranged from -.10 to .38 , and the combined effect size was $r=.21(n=185 ; p=.006)$ in a homogeneous set of outcomes.

Marital discord. Owen and Cox (1997) suggested that children witnessing marital discord may experience disorganizing fright from their attachment figure, and they proposed marital discord as one of the alternative pathways to disorganization of attachment. In their study on 38 mothers and 33 fathers, Owen and Cox (1997) found impressive effect sizes ( $r=.40$ and $r=.45$, respectively), but in studies by Radke-Yarrow, Cummings, Kuczynski, and Chapman (1985), Shaw, Owens, Vondra, Keenan, and Winslow (1996), and Moss, Rousseau, Parent, St-Laurent, and Saintonge (1998) this outcome was not replicated at $r=.04, n=95 ; r=.07, n=77$; and $r=-.19, n=121$, respectively. In the four studies on $n=364$ participants, the combined effect size was $r=.05$ (n.s.). In the studies using the Main and Solomon (1990) coding system (Owen \& Cox, 1997; Shaw et al., 1996), the combined effect size was $r=.25$ ( $p=$ .007).

Parental depression. Because parental depression leads to temporary and potentially unpredictable inaccessibility of the parent, it has been considered to be another cause of attachment disorganization in the child (Solomon \& George, 1994; DeMulder \& Radke-Yarrow, 1991; Lyons-Ruth, Connell, Grunebaum, \& Botein, 1990). Sixteen studies on depression and disorganization were available, including $n=1,053$ participants. The combined effect size amounted to $r=.06(p=.06)$ in a homogeneous set of study outcomes (see Table 6). The eleven studies with Main and Solomon (1990) classifications showed a similar combined effect size of $r=.09$. Publication year, SES, age of parent, and type of depression assessment were not significant as predictors of study outcome, and blocking of the one study on bipolarly depressed mothers only (DeMulder \& Radke-Yarrow, 1991) versus the other studies did not yield a significant contrast, $p=.15$. Sample size and age of the child at the Strange Situation were significant as predictors; however, larger samples and samples with older children yielded smaller effect sizes. The contrast between studies on clinically depressed and community samples was significant, $z=2.24, p=.01$; the combined effect size for the community samples was $r=$ $-.01(k=7$, n.s.), whereas for the samples with clinically depressed subjects it was $r=$ $.13\left(k=9, p_{1}=.003\right)$. Both sets of studies were homogeneous.

The large NICHD study on daycare (NICHD Early Child Care Research Network, 1997) confirmed the absence of a substantial association between depression and disorganization. In this study on 1,131 one-year-olds, psychological adjustment of the mothers was assessed with the CES-D scale for depression (Radloff, 1977) and the NEO personality inventory (Costa \& McRae, 1985). Psychological adjustment of the mothers was not related to infant disorganized attachment (re-computed effect size was $r=.04$ ). 
Table 6. Parental depression and disorganized child attachment

\begin{tabular}{|c|c|c|c|c|c|c|c|c|c|}
\hline & & & & A & ge & & & & \\
\hline & Study & $n$ & SES & Child & Parent & Depression $^{a}$ & Main & Statistic & Size $(r)$ \\
\hline 1 & Dawson et al (1992) & 34 & Low & 14 & 19 & & $\mathrm{y}$ & $\chi^{2}=007$ & 05 \\
\hline 2 & Frankel \& Harmon (1996) & 62 & Diverse & 36 & 34 & $\begin{array}{l}\text { SADS } \\
\text { (RDC) }\end{array}$ & $n$ & $\chi^{2}=194$ & -18 \\
\hline 3 & Heller \& Zeanah (1996) & 17 & Middle & 12 & 31 & BDI & $\mathrm{y}$ & $F=427$ & 46 \\
\hline & Hubbs-Tait e & 44 & Low & 13 & 18 & & J & $r=15$ & 15 \\
\hline & Tet1 et al (1995) & 50 & Middle & $12-21$ & 30 & BDI & $\mathrm{y}$ & $\chi^{2}=536$ & 33 \\
\hline & Tet1 et al (1995) & 54 & Middle & 21 & 30 & $\mathrm{BDI}$ & $\mathrm{n}$ & $\chi^{2}=337$ & 25 \\
\hline 7 & Murray (1992) & 104 & Diverse & 18 & 28 & $\begin{array}{l}\text { SADS } \\
\text { (RDC) }\end{array}$ & $\mathrm{y}$ & $x^{2}=240$ & 15 \\
\hline & $\begin{array}{l}\text { DeMulder \& Radke- } \\
\text { Yarrow (1991) (bipolar) }\end{array}$ & 59 & Middle & $15-52$ & 32 & $\begin{array}{l}\text { SADS } \\
\text { (RDC) }\end{array}$ & $\mathrm{n}$ & $\chi^{2}=468$ & 28 \\
\hline 9 & $\begin{array}{l}\text { DeMulder \& Radke- } \\
\text { Yarrow (1991) (unipolar) }\end{array}$ & 78 & Middle & $15-52$ & 32 & $\begin{array}{l}\text { SADS } \\
\text { (RDC) }\end{array}$ & $n$ & $\chi^{2}=000$ & 01 \\
\hline 10 & Shaw et al (1996) & 85 & Low & 12 & $17-36$ & $\mathrm{BDI}$ & $\mathrm{y}$ & $r=04$ & 04 \\
\hline & $\begin{array}{l}\text { Lyons-Ruth et al (1990) } \\
\text { (high risk) }\end{array}$ & 10 & Low & 18 & 22 & CES D & $\mathrm{y}$ & $\chi^{2}=127$ & 36 \\
\hline 12 & $\begin{array}{l}\text { Lyons-Ruth et al (1990) } \\
\text { (community) }\end{array}$ & 32 & & 1 & 2 & $\mathrm{c}$ & $y$ & $\gamma^{2}=029$ & 09 \\
\hline 13 & Schuengel et al (1999) & 85 & Middle & 14 & 31 & EPDS & y & $t=-080$ & -09 \\
\hline & $\begin{array}{l}\text { Selfer, Sameroff, et al } \\
\text { (1996) }\end{array}$ & 116 & & & & & & & 08 \\
\hline 15 & Beeghly et al (1997) & 102 & Middle & 12 & 33 & $-\mathrm{D}$ & $y$ & $r=-03$ & $\begin{array}{r}-03 \\
-03\end{array}$ \\
\hline 16 & Moss et al (1998) & 121 & Diverse & 75 & - & BDI & $n$ & $t=-093$ & $3-09$ \\
\hline Cor & mbined & $=1,05$ & & & & & & & $r=06$ \\
\hline
\end{tabular}

"CES-D Center for Epıdemıological Studies Depression scale, BDI, Beck Depression Inventory, SADS, Schedule for Affective Disorders and Schizophrenia, EPDS, Edınburgh Postnatal Depression Scale, HRSD, Hamilton Ratıng Scale of Depression

'Main and Solomon (1990) coding system for D (y, yes $n$, no)

Parental insensitivity Disorganized attachment is considered to be different from organized insecure attachment patterns in that regular parental insensitivity is supposed to be associated with insecurity (De Wolff \& van Ijzendoorn, 1997) but not with disorganization (Main \& Hesse, 1990) In 13 studies on $n=1,951$ participants, the association between infant disorganization and parental insensitivity was examined The combined effect size was significant but small $r=10$ ( $p=004)$, in a heterogeneous set of study outcomes, $\chi^{2}(12)=237, p=02$ (see Table 7) Only sample size was a significant predictor of variation in effect sizes larger samples showed smaller effects To check the influence of the large NICHD sample (NICHD Early Child Care Research Network, 1997), we computed the combined effect size with a weighting of unit 1 The resulting combined effect size was $r=16(p<001)$ All studies except the one of Moss et al (1998) included in this analysis used the Main and Solomon (1990) coding system for disorganized attachment, exclusion of this study did not yield different results

Parental dissociation and frightening behavlor Because early loss and trauma in parents seemed to be related to infant disorganized attachment, Liott1 (1992) and Main and Morgan (1996) proposed a dissociative model to explain the emergence of disorganized infants Only in two studies dissociative tendencies have been assessed directly (Lyons-Ruth \& Block, 1996, Schuengel, Bakermans-Kranenburg, \& Van Ijzendoorn, 1999) Both studıes used the self-report Dissociative Experiences 
Table 7. Parental insensitivity and disorganized attachment

\begin{tabular}{|c|c|c|c|c|c|c|c|}
\hline \multirow[b]{2}{*}{ Study } & \multirow[b]{2}{*}{$n$} & \multirow[b]{2}{*}{ SES } & \multicolumn{2}{|c|}{ Age } & \multirow[b]{2}{*}{ Sensitıvity } & \multirow[b]{2}{*}{ Statistic } & \multirow{2}{*}{$\begin{array}{c}\text { Effect } \\
\text { Size }(r)\end{array}$} \\
\hline & & & Attachment & Sensitivity & & & \\
\hline 1 NICHD (1997) & 1,151 & Diverse & 15 & $6+15$ & Home & $t=162$ & 05 \\
\hline 2 Schuengel et al (1999) & 85 & Middle & 14 & 10 & Home & $t=-016$ & -02 \\
\hline 3 Seifer, Schiller, et al (1996) & 49 & Middle & 12 & $4-12$ & Home & $p=50$ & 00 \\
\hline 4 Hunt et al (1997) & 40 & Low & 25 & 25 & Lab & $t=045$ & 09 \\
\hline 5 Spangler et al (1996) & 88 & Diverse & 12 & $2-10$ & Home & $p=50$ & 09 \\
\hline 6 Carlson (1998) & 129 & Low & $12-18$ & 6 & Home & $r=38$ & 38 \\
\hline 7 Lyons-Ruth et al (1990) & 38 & Low & 18 & $5-18$ & Intervention & $\chi^{2}=082$ & 15 \\
\hline 8 Tet1 et al (1995) & 50 & Middle & $12-21$ & $12-21$ & Home & $t=122$ & 18 \\
\hline 9 Owen \& Cox (1997) (mothers) & 38 & Middle & $12-15$ & 3 & Home & $r=29$ & 29 \\
\hline 10 Owen \& Cox (1997) (fathers) & 33 & Middle & $12-15$ & 3 & Home & $r=17$ & 17 \\
\hline 11 Zevalkınk (1997) & 46 & Low & $12-30$ & $12-30$ & Home & $F=459$ & 30 \\
\hline \multicolumn{8}{|l|}{12 Bakermans-Kranenburg \& } \\
\hline Van IJzendoorn (1997) & 83 & Middle & 12 & 12 & $\mathrm{Lab}$ & $r=24$ & 24 \\
\hline 13 Moss et al (1998) & 121 & Diverse & 75 & 75 & $\mathrm{Lab}$ & $t=221$ & 20 \\
\hline Combıned & $N=1,951$ & & & & & & $r=10$ \\
\hline
\end{tabular}

Note All studies except the one by Moss et al (1998) used the Main and Solomon (1990) coding system for disorganızed attachment

Scale (DES, Bernstein \& Putnam, 1986, Van Ijzendoorn \& Schuengel, 1996) and the Main and Solomon (1990) coding system for disorganized attachment In the first study, mothers with disorganized infants had either high scores on the DES and PTSD scales or low scores on both these scales Mothers with infants not classified as disorganized scored high on only one of the two scales In the Lyons-Ruth and Block (1996) and the Schuengel et al (1999) studies, the bivariate associations between maternal DES scores and infant disorganızed attachment were not significant

Main and Hesse's (1990) suggestion of a link between frightenıng parental behavır and disorganized infant attachment has only been tested in two observational studies (Lyons-Ruth et al , 1997, Schuengel et al , 1999) Schuengel et al (1999) found an association between frightening maternal behavior at home and disorganization of infant attachment, $r=19(n=85)$, whereas Lyons-Ruth et al (1997), observing frightening as well as other atypical maternal behavior, found an effect size of $r=34(n=52)$ It should be noted that Schuengel et al (1999) also documented the protective role of secure attachment representations as secure mothers with uniesolved loss showed significantly less frightening behavior than their insecure counterparts Only in the group of insecure mothers, the Main and Hesse (1990) model of a link between maternal unresolved loss, mildly frightening and frightened maternal behavio1, and infant disorganızed attachment was confirmed

\section{Sequelae of disorganized attachment}

Stress reaction In two studies the effect of stress on the saliva cortisol levels of 1-yearold disorganized infants was assessed Spangler and Grossmann (1993) found elevated cortisol levels in their 32 German infants from divers socioeconomic backgrounds $15 \mathrm{~min}$ after the Strange Situation procedure (effect size $r=14$ ) Hertsgaard et al (1995) were able to replicate this outcome in an American low SES sample of 35 infants, they assessed cortisol levels 10 min after the Strange Situation procedure and found an effect size of $r=$ 33 The combined effect size amounted to $r=24(p=03)$ Disorganized children seem to be least able to cope with the stress of the separations and reunions because they lack a consistent strategy of dealing with negative emotions The organized attachment classifications did not differ in cortisol levels The 
studies used the Main and Solomon (1990) coding system for disorganized attachment. In the Willemsen et al. (1998) study on autistic and language-delayed children, disorganized children also seemed to be stressed more by the separation from their parent than organized children, as was indicated by heart rate assessments.

Externalizing problem behavior. In her narrative review on precursors of aggression in children, Lyons--Ruth (1996) concluded that disorganized attachment in infancy predicted aggression in school age children. In our meta-analysis on 12 studies involving 734 participants, we confirmed this conclusion (see Table 8). The combined effect size across the 12 studies was $r=.29$, and the set of study outcomes was homogeneous. The selection of problem behavior assessments was based on the following criteria: If more times of measurements were included we chose the earliest assessment; if it was possible to choose between mother-reported or teacher/observer reported problem behavior the latter assessment was chosen; the most specific indicator of aggressive or externalizing problem behavior was preferred, such as the CBCL scale for externalizing behavior (Achenbach, 1985). Mean age of attachment assessment was 39 months, and mean age of problem behavior assessment was 59 months. Age was not a significant predictor of the variation in effect sizes, and the same was true for the use of the CBCL versus the other measures. The studies using the Main and Solomon (1990) coding system showed the same combined effect size of $r=.29$.

Altered states of mind. Liotti (1992) and Hesse and Main (in press) proposed that parents who enter somewhat altered states of mind may be frightening to the child who may become disorganized. Disorganized attachment behaviors have been compared to dissociative behaviors and several similarities have been uncovered (Main \& Morgan, 1996). The issue is whether disorganized infants will later in life be inclined to get involved into altered states of mind such as absorption or dissociation. Indirect evidence was provided by a retrospective study in which individuals whose parents had lost another child-or another loved one-within 2 years preceding or following their birth showed elevated propensities towards absorption as measured by Tellegen's Absorption Scale (Hesse \& Van Ijzendoorn, 1998). Another study looking at the same type of losses showed an elevated risk of developing a dissociative symptoms (Liotti, 1992). The assumption is that loss around birth enhances the risk for the infant of becoming disorganized. Carlson's (1998) longitudinal study provided the direct evidence for the association between disorganized infant attachment and dissociative tendencies later in life. In a low SES sample 128, 17-year-old participants who were observed in the Strange Situation procedure in their second year of life, completed the Dissociative Experiences Scale. Carlson (1998) found a strong association of $r=.36$ between dissociation and disorganization.

\section{Discussion and Conclusions}

During the past 10 years nearly 80 studies on disorganized attachment involving more than 6,000 infant-parent dyads have been carried out. These studies document the importance of disorganized attachment in the development of child psychopathology, in particular the emergence of externalizing problem behaviors. The current series of meta-analyses have established the reliability and discriminant validity of disorganized infant attachment. Although disorganized attachment behavior is necessarily difficult to observe and often subtle, many researchers have managed to become reliable coders. Furthermore, disorganized attachment shows short-and longterm stability, in particular in stable, middleclass environments, and we proved that it is not just a concomitant of constitutional, temperamental, or physical problems. The predictive validity of disorganized attachment is established in terms of problematic stress management, the elevated risk of externalizing problem behavior, and the tendency of disorganized infants to show dissociative behavior later in life (Carlson, 1998). In normal, 


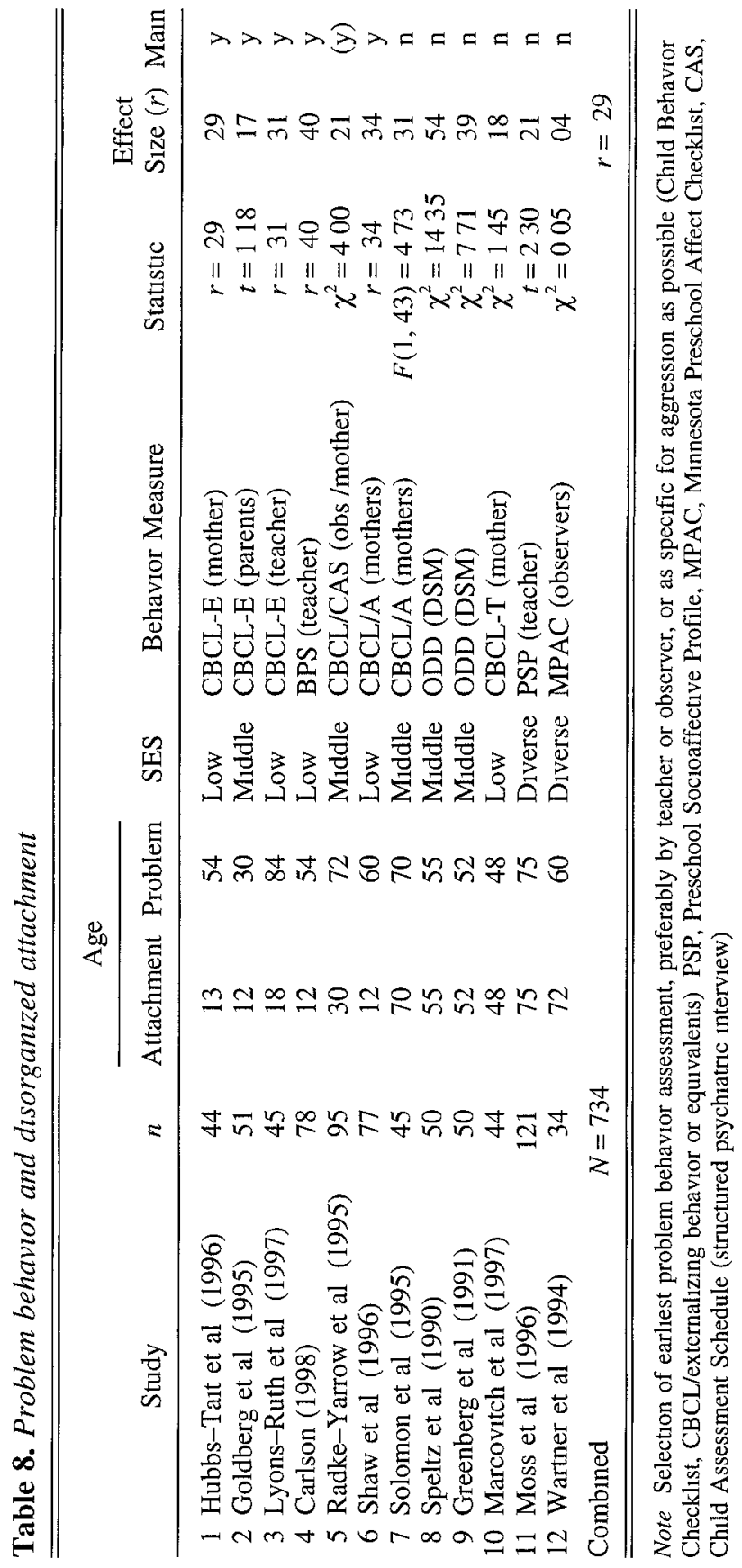


middle-class families, about $15 \%$ of the infants develop disorganized attachment behavior. In other social contexts and in clinical groups this percentage may become 2 or even 3 times higher. Although the importance of disorganized attachment for developmental psychopathology is evident, the search for the mechanisms leading to disorganization has just started. Frightening or frightened and dissociated parental behavior may play an important role but it does not seem to be the only causal factor involved in the emergence of disorganized attachment (Hesse \& Main, in press).

Across all studies, the intercoder reliability for disorganized attachment has been sufficient for research purposes (generally at least $80 \%$ agreement on the D/non-D classification, with $\kappa$ 's higher than .60 ). But even expert raters do not reach a maximum agreement on disorganized attachment classifications. On the $A, B, C, D$ classifications, expert raters trained by Mary Main who, with Judith Solomon, developed the coding system for identifying $D$ in the Strange Situation, reached $\kappa s$ ranging from .69 to .76 (Lyons-Ruth et al., 1997; NICHD Early Child Care Research Network, 1997; Sagi, Van Ijzendoorn, Aviezer, \& Donnell, 1994). For diagnostic purposes, the coding system is complicated and the intercoder reliability only marginal. The Strange Situation procedure may offer too small a window on infants' behavior under stress to exclude the possibility of false negatives. For research, as well as for diagnostic purposes, two ways of improving the assessment of disorganized attachment may be considered. First, naturally occurring stressful situations may be observed for additional signs of disorganized attachment. In the literature, at least one case has been described of an infant who showed clear-cut disorganized attachment behavior at home, but not in the Strange Situation procedure (Schuengel, Van Ijzendoorn, Bakermans-Kranenburg, \& Blom, 1997). In this case, the detection of disorganized attachment at home took, however, almost $4 \mathrm{hr}$ of videotaped observations. Furthermore, the attachment figure may not always show the behavior that triggers a disorganized response of the infant. Ethically acceptable ways of induc- ing these triggering behaviors in the parent should be searched for. Second, because disorganization of attachment is expressed in problematic management of stress and in problematic regulation of negative emotions, salivary cortisol levels or heart rate may be used as additional markers of disorganized attachments in conjunction with behavioral indices. During and shortly after stressful separations disorganized children show more physiological stress than organized children (Hertsgaard et al., 1995; Spangler \& Grossmann, 1993; Willemsen et al., 1998), and elevated stress levels might be used to start a more thorough search for disorganized behavior, for example in the home setting. The associations between physiological indices and disorganization, however, are far from perfect. Furthermore, the inclusion of physiological indices in research or in clinical diagnoses of disorganized attachment may not always be feasible.

The test-retest reliability or stability of disorganized attachment is modest. It is unclear why the stability of disorganized attachment tends to be higher in middle-class groups. In the case of the organized attachment classifications, higher stability for middle-class groups would be expected because of middleclass child rearing arrangements being more stable (Vaughn, Egeland, Sroufe, \& Waters, 1979). Disorganized attachment, however, may be the consequence of unpredictable, frightening parental behavior which may be more stable in lower class homes with more life stresses and more chaotic child rearing arrangements. On the other hand, not every kind of unpredictable or even chaotic behavior may lead to disorganization. It may be specifically unpredictably frightening behavior that is the key. One might speculate that under low-risk circumstances frightening parental behavior is more salient and less predictable, and has a more stable influence on infant attachment. This hypothesis requires further study of the causal role of frightening behavior in different ecological contexts. Lastly, the intercoder reliability poses a limit on the stability. If we correct the stability correlation with the intercoder reliability of .76 (Sagi et al., 1994, between Marinus van Ijzendoorn and Mary 
Main), the stability becomes .46 for the set of studies, in which the Main and Solomon (1990) coding system was used to establish short-term stability. The disorganized attachment category is not less stable than the other attachment classifications (Belsky, Campbell, Cohn, \& Moore, 1996; Thompson, in press), and Bowlby (1973/1985) already predicted the dependence of attachment on contextual stability during the first few years of life.

Disorganized attachment appears to be characteristic of a specific relationship. The correspondence between infant-mother and infant-father disorganized attachment is low, and comparable to the correspondence between infant-mother and infant-father security of attachment (Van Ijzendoorn \& De Wolff, 1997). Constitutional or temperamental characteristics of the child do not seem to contribute to disorganized attachment status. Boys have been speculated to be more liable to become disorganized than girls are, but the meta-analytic data do not confirm this contention. In attachment research, surprisingly few sex differences have been found (Benenson, 1996). Disorganized attachment cannot be considered to be the consequence of a difficult temperament either. Temperament assessments have been routinely included in many attachment studies, and examination of the pertinent data on 1,790 children revealed the absence of a correlation with disorganized attachment. Physical problems such as cleft palate (Speltz et al., 1997) are also not related to attachment disorganization. Only neurological abnormalities may increase the likelihood of disorganized behavior, for example, in Downs syndrome children (Vaughn et al., 1994) or in autistic children (Capps et al., 1994; Willemsen et al., 1998). Pipp-Siegel et al. (1997) correctly emphasize the potential neurological basis of many disorganized behaviors, and further research is needed to test the predictive validity of disorganized attachment behavior in groups at risk for neurological impairments.

Disorganized infant attachment is not just the consequence of parental insensitivity. Across almost 2,000 infant-parent dyads, the correlation between parental insensitivity and infant disorganization was only .10 . In a re- cent meta-analysis on parental insensitivity and infant attachment insecurity, the effect size was equivalent to a correlation of .24 . Within the normal, nonclinical range of parenting, insensitive parental behavior does not seem to be sufficient to evoke disorganized attachment behaviors in the child. It is clear, however, that maltreatment is an important antecedent of disorganized attachment. It is plausible that the real fright involved in this type of extremely insensitive and disturbed parenting results in a temporary breakdown of the child's regular strategy to deal with negative emotions in the face of stress. Another behavioral precursor of disorganized attachment might be frightening parental behavior in the absence of maltreatment. Hesse and Main (in press) speculated about the mechanism connecting unresolved loss in the parent with infant disorganization, and following $\mathrm{Li}$ otti (1992), they proposed a dissociative model in which unresolved parents' elevated propensity to dissociated behavior may cause fright in the child. The role of "dissociated" frightening behavior as opposed to real frightening interaction, however, is less clear-cut. Only two studies on the association between parental dissociation, frightening parental behavior, and disorganization have been performed, and the results are promising but need further replication (Lyons-Ruth et al., 1997; Schuengel et al., 1999). Several hours of home observation in nonclinical families were necessary to pinpoint the low frequency frightening and frightened parental behavior in the natural setting (Schuengel et al., 1999). The study of the dissociative model would become intensified if in controlled experiments frightening parental behavior could be simulated, for example through a still-face procedure.

Beside real and dissociated frightening behavior, disorganized children might experience "conflictual" frightening behavior as a consequence of witnessing chronic marital discord. Owen and Cox (1997) speculate about the disorganizing features of intensive marital discord, and they emphasize the frightening nature of the exposure to continuous marital conflict (Davies \& Cummings, 1994). Marital discord may evoke role reversing and even 
controlling behavior in the older child who plays the role of protective care giver for one of the parents. Controlling behavior has been suggested to be the expression of attachment disorganization in preschoolers and schoolage children (Main \& Cassidy, 1988). The empirical evidence for this model, however, is still scant as well as equivocal. Nevertheless, it concurs with Solomon and George's (1994) suggestion that parents who go through a divorce may feel unable to protect the child against the risks of interacting with the other parent and thereby fail to fulfill the basic role of an attachment figure. The breakdown of the protective parental role may lead to a breakdown of organized attachment patterns in the child. In this context, the association between parental depression and infant disorganization is disappointingly weak-in nonclinical groups, as well as in clinically depressed samples. Depressed parents may become withdrawn from their parental role, and feel incompetent to respond to their child's basic attachment needs. Parental bipolar depression may be especially frightening for children who are confronted with unpredictability and temporary inaccessibility of their attachment figure without being able to see its reason or cause. Further research on bipolar depression is needed to settle this issue more definitely (DeMulder \& Radke-Yarrow, 1991; Radke-Yarrow, McCann, DeMulder, Belmont, Martinez, \& Richardson, 1995). Furthermore, severely and chronically depressed parents have been studied less frequently. Severe and long-lasting parental depression may lead to highly incompetent parenting and to disorganization of attachment (Teti, Messinger, Gelfand, \& Isabella, 1995). More empirical work is needed to address this issue metaanalytically in a more balanced way.

In 12 studies on 734 children, disorganized attachment was associated with more externalizing problem behavior as assessed by parents, teachers, or observers. The effect size is substantial, and the association appears to hold across extended periods of time, from infancy into the school-age period, and even beyond (Carlson, 1998). Disorganized attachment may certainly be considered an important risk factor in the development of child psychopathology. Combined with the elevated cortisol levels of disorganized children after stress, and their inclination to enter into somewhat dissociated states, this result may even lead to the suggestion that disorganized attachment is an early sign of psychopathology in itself. In the absence of any systematic validation of the reactive attachment disorders as defined in the DSM-IV (American Psychiatric Association, 1994; Zeanah et al., 1997), disorganized attachment may become the focus of clinical attempts to assess at least one important dimension of the reactive attachment disorders at an early stage in life. For two reasons, we should be cautious, however, about the diagnostic use of disorganized attachment. First, the meta-analytic evidence presented in this paper is only correlational and the causal nature of the association between disorganized attachment and externalizing problem behavior still has to be established. Experimental intervention studies may settle this issue if the intervention is explicitly directed at a change in that parental behavior or mental state that provokes disorganized behavior in the child. Second, the specificity of the consequences of disorganized attachment still is unclear. Externalizing problem behavior and dissociative tendencies seem rather diverging sequelae, and empirical evidence for a specific common thread is still lacking (Putnam, 1997). Disorganized attachment should predict problems in emotion regulation and control, and it should have less influence, for example, on problems in the cognitive domain or in language development.

Whereas disorganized attachment is a risk factor in developmental psychopathology, secure attachment may be considered a protective factor, which may buffer the potential negative effects of disorganization. In her longitudinal study on a high-risk sample, LyonsRuth and her coworkers did not find a significant buffering effect on internalizing and externalizing problem behavior (Lyons-Ruth et al., 1997). The number of disorganized children with a secondary secure strategy was small $(n=4)$, however. Spangler and Grossmann (1993) showed in their cortisol study that disorganized infants with a secondary secure strategy were more stressed than their (organized) secure and insecure counterparts. Because the power of statistical analyses on 
small subgroups is rather weak, replications in further studies with larger samples are necessaty In our meta-analyses, we were unable to test for differences between alternate and secondary classifications because the primary studies did not provide sufficiently detailed data Besides secondary security of the infant, also security of attachment representations in the parents may be a protective factor In a study on nonclinical, middle-class mothers with and without unresolved loss, we showed that Main and Hesse's (1990) model of frightenıng behavior as the mechanısm between parents' unresolved loss and infants' disorganized attachment is valid only for insecuie mothers. Unresolved mothers with secure attachment representations show significantly less frightenıng behavior and thus prevent their children from becoming disorganized (Schuengel et al, 1999). This study is the first complete test of the dissociative model of disorganized attachment, and replications should be carried out to see whether the role of attachment as a protective as well as a rısk factor can be substantiated

\section{References}

Achenbach, T M (1985) Assessment and taxonomy of child and adolescent psychopathology London Sage

Ainsworth, M D S, Blehar, M C, Waters, E, \& Wall, $S$ (1978) Patterns of attachment Hillsdale, NJ E1lbaum

Ainsworth, M D S, \& Eichberg, C G (1991) Effects on infant-mother attachment of mother's uniesolved loss of an attachment figure or other traumatic experience In $\mathrm{C}$ M Parkes, $\mathbf{J}$ Stevenson-Hinde, \& $\mathrm{P}$ Marris (Eds), Attachment across the life cycle ( $\mathrm{pp}$ 160-183) London Routledge

American Psychiatric Association (1994) Diagnostic and statistical manual of mental disorders (4th ed) Washington, DC Author

Ammanıtı, M , \& Speranza, A M (1995) Maternal xep resentations and disoiganized patteins of attachment in children Giornale di Neuropsychatria-dell'Eta Evolutiva 15, 27-34

Bakermans-Kranenbuig, M I , \& Van Ijzendooin, M H (1997) Stability of disorganized attachment in the second year of life Unpublished manuscupt, Leiden University

Barnett, D, Ganıban, J, \& Cicchett1, D (1997) Mal treatment, emotional reactlvity, and the development of type $D$ attachments from 12 to 24 months of age Unpublished manuscript

Beeghly, M , \& Cicchett, D (1994) Child maltreatment, attachment, and the self system Emergence of an internal state lexicon in toddlers at high social $11 \mathrm{sk} D e$ velopment and Psychopathology, 6, 5-30

Beeghly, M, Nelson, K M, Olson, K L, Kernan, H, Markov, Y, Weinberg, M K, \& Tionick, E Z (1997, April) Effects of maternal depression on $\mathrm{m}$ fant attachment in a low risk sample Paper presented at the Biennial Meeting of the Society for Research in Chıld Development, Washıngton, DC

Belsky, J, Campbell, S, Cohn, J F, \& Moore, G (1996) Instability of infant parent attachment security Developmental Psychology 32, 921-924

Benenson, J F (1996) Gender differences in the development of relationships In $\mathrm{G} \mathrm{G}$ Noam \& $\mathrm{K}$ W F1scher (Eds), Development and vulnerablity in close relationships (pp 263-286) Hillsdale, NJ Erlbaum

Benott, D , \& Parker, K C H (1994) Stability and tiansmission of attachment across 3 generations Chld De velopmeni, 65,14441456

Bernstein, E M , \& Putnam, F W (1986) Development,

reliability, and validity of a dissociation scale The Joun nal of Nervous and Mental Disease, 174, 727735

Bıshop, Y Y, Fienberg, S E, \& Holland, P W (1975) Discrete multrvartate analys 1 S Theory and practice Cambridge, MA MIT Press

Boris, N W, Fuevo, M, \& Zeanah, C H (1997) The clinical assessment of attachment in children under five Journal of the American Academy of Chld and Adolescent Psychatry 36 291-293

Bowlby, J (1985) Sepaiaton Anxiety and anger London Penguin (Original work published 1973)

Broussard, E R (1995) Infant attachment in a sample of adolescent mothers Chld Psychatrv and Human Development, 25, 211-219

Capps, L , Sigman, M , \& Mundy, P (1994) Attachment security in children with autism Development and Psychopathology, 6, 249-261

Carlson, E A (1998) A piospective longitudinal study of disorganized/disortented attachment Chld Devel opment, 69, 1107-1128

Carlson, V, Cicchettı, D, Barnett, D, \& B1aunwald, K (1989) Disotganızed/disoriented attachment relation shups in maltreated infants Developmental Ps) chology, 25, 525-531

Cassidy, J , Marvin, R S , \& MacArthur Wo1kıng Group on Attachment (1992) Attachment organization in three-and four yeal olds Procedures and coding manual Unpublished coding manual, Pennsylvania State University

Chatoor, I, \& Ganıban, J (1998, April) Attachment and feeding problems Reexammation of non organc falure to thrive and attachment securty Poster piesented at the Biennial Meeting of the Inter national Socrety for Infant Studies, Atlanta, GA

Cicchett1, D, \& Banett, D (1991) Attachment organization in maltieated preschoolers Special Issue Attachment and developmental psychopathology Development and Psychopathology 3 397-411

Claussen, A H, Mundy, P C, \& Willoughby J C (1998, April) Nonverbal conmunication, joint attention and attachment in infants at risk Poste1 presented at the Brennial Meeting of the Inter national Socrety for Infant Studies, Allanta, GA

Cohn, D A (1990) Child-mother attachment of s1xyear olds and social competence at school Child De velopment, 61, 152-162 
Costa, P T , \& McRae, R R (1985) The NEO Personaltty Inventory manual Odessa, FL Psychological Assessment Resources

Cox, S M (1995, March) Maternal chldhood history as a predictor of disorganized attachment in preterm infants Poster presented at the Biennial Meeting of the Socıety for Research in Child Development, Ind1anapolis, IN

Crittenden, P M (1985) Maltreated infants Vulnerabilily and resilience Journal of Child Psychology and Psychiatry and Alled Disciplines, 26, 85-96

Crittenden, P M (1988) Relationships at risk In J Belsky \& T Nezworski (Eds), Clinical implications of attachment (pp 136-174) Hillsdale, NJ Erlbaum

Crittenden, P M (1992) Quality of attachment in the preschool years Development and Psychopathology, 4, 209-241

Crittenden, P M , \& Ainsworth, M D S (1989) Child maltreatment and attachment theory In $\mathrm{D}$ Cicchett1 \& V Carlson (Eds), Child maltreatment The ory and research on the causes and con sequences of child abuse and neglect (pp 432-463) New York Cambridge University Press

Davies, P T, \& Cummings, E M (1994) Marital conflict and child adjustment An emotional security hypothes1s Psychological Bulletin, 116, 387-411

Das Eıden, R, \& Leonard, K E (1996) Paternal alcohol use and the mother infant relationship Development and Psychopathology, 8, 307-323

Dawson, G, Grofer Klinger, L, Panagiotıdes, H, Spieker, S , \& Frey, K (1992) Infants of mothers with depressive symptoms Electroencephalographıc and behavioral findings related to attachment status Development and Psychopathology, 4, 67-80

DeKlyen, M (1996) Disruptive behavior disorder and intergenerational attachment patterns A comparison of clinic referred and normally functioning preschoolers and their mothers Journal of Consulting and Clinical Psychology, 64, 357-365

DeMulder, E K, \& Radke--Yarrow, M (1991) Attachment with affectively ill and well mothers Concurrent behavioral correlates Development and Psychopathology, 3, 227-242

DeWolff, M S , \& Van Ijzendoorn, M H (1997) Sensitivity and attachment A meta-analysis on parental antecedents of infant-attachment Chlld Development, $68,571-591$

Dozier, M , \& Kobak, R R (1992) Psychophysiology in attachment interviews Converging evidence for deact1vatıng strategies Child Development, 63, 14731480

Easterbrooks, M A, Davidson, C E, \& Chazan, R (1993) Psychosocial risk, attachment, and behavior problems among school-aged children Development and Psychopathology, 5, 389-402

Fish, M, \& Fish, S E (1998, April) Temperament, attachment, and heart rate variability Comparisons of secure, avoidant, and disorganized infants Poster presented at the Biennial Meeting of the International Society for Infant Studies, Atlanta, GA

Fish, M , \& Stıfter, C A (1995) Patterns of mother infant interaction and attachment A cluster-analytic approach Infant Behavior and Development, 18, 435446

Frankel, K K , \& Harmon, R J (1996) Depressed mothers They don't always look as bad as they feel Journal of the American Academy of Child and Adolescent Psychiatry, 35, 289-298
George, C (1996) A representational peispective of child abuse and prevention Internal working models of attachment and caregiving Child Abuse \& Neglect, $20,411-424$

George, C, Kaplan, N , \& Main, M (1985) Adult attachment interview Unpublıshed manuscript, Unıversity of Calıfornı at Berkeley

Goldberg, S, Gotowiec, A , \& Simmons, R J (1995) Infant-mother attachment and behavior problems in healthy and chronically 11 preschoolers Development and Psychopathology, 7, 267-282

Goldberg, S, Lojkasek, M, Gartner, G, \& Corter, C (1989) Maternal responsiveness and social development in preterm infants In $\mathrm{MH}$ Bornstein (Ed), Maternal responsiveness Characteristics and conse quences New Directions for Chld Development (pp 89-103) San Francisco Jossey-Bass

Greenberg, M T, Speltz, M L, \& DeKlyen, M (1993) The role of attachment in the early development of disruptive behavior problems Special Issue Toward a developmental perspective on conduct disorder $D e$ velopment and Psychopathology, 5, 191-213

Greenberg, M T, Speltz, M L, DeKlyen, M, \& Endriga, M C (1991) Attachment security in preschoolers with and without exteinalizing behavioi problems A replication Special Issue Attachment and developmental psychopathology Development and Psychopathology, 3, 413-430

Harrison, L J, \& Ungerer, J A (1996) Maternal employment, infant child care and securty of attachment at age 12 months Paper presented at the XXVI International Congress of Psychology, Montreal, Canada

Hedges, L V (1986) Issues in meta-analysis Review of Research in Education, 13, 353-399

Hedges, L V, \& Olkin, I (1985) Statisttcal methods for meta-analysis Orlando Academic Press

Heller, S S, \& Zeanah, C H (1996) Attachment disturbances in infants born subsequently to permatal loss Unpublished manuscript, Louisiana State Un1versity

Hertsgaard, L, Gunnar, M, Enıckson, M F, \& Nachmias, M (1995) Adrenocortical responses to the strange situation in infants with disorganized/disoriented attachment relationships Child Development, 66, 1100-1106

Hesse, E , \& Main, M (1n press) Frightened behavior in traumatızed but non-maltreatıng parents Previously unexamined risk factor for offspring Psychoanalytic Inquiry

Hesse, E, \& Van Ijzendoorn, M H (1998) Parental loss of close family members and propensities towards absoiption in offspring Developmental Science, I, 299305

Howes, C , \& Hamilton, C E (1992) Childrens relationships with child care tcachers stability and concordance with parental attachments Child Development, $63,867-878$

Hubbs-Tatt, L, Hughes, K P, Culp, A M, Osofsky, J D, Hahn, D M, Eberhartwright, A, \& Ware, L M (1996) Children of adolescent mothers Attachment representation, maternal depression, and later behavior problems American Journal of Orthopsychtatry, 66, 416-426

Hunt, K H, Barnett, D, McCaskill, J, Butler, C, Kaplan-Estrin, M , \& Behen, M (1997) Attachment and parenting among toddlers with birth defects Poster presented at the Biennial Meeting of the Society for Research in Chıld Development, Washıngton DC 
Jacobsen, T, Edelsteın, W, \& Hofmann, V (1994) A longitudinal study of the relation between representations of attachment in childhood and cognitive functioning in childhood and adolescence Developmental Psychology, 30, 112-124

Jacobsen, T, \& Hofmann, V (1997) Childrens attachment representations Longitudinal relations to school behavior and academic competency in middle childhood and adolescence Developmental Psychology, $33,703-710$

Jacobsen, T, Huss, M, Fendrich, M, Kruesı, M P, \& Ziegenhain, U (1997) Chıldren's abılity to delay gratıfication Longitudinal relations to mothel-child attachment Journal of Genetk Psychology, 158, 411-426

Johnson, B T , Mullen, B , \& Salas, E (1995) Compar1son of three majos metd-analytic approaches Journal of Applied Psychology, 80, 94-106

Kroonenberg, P M (1998) Multinom for Windows (Version 2 0a) [Computes software] Leiden, The Netherlands Leiden Unuversity Avatlable http // www fsw leidenuniv $\mathrm{nl} / \sim \mathrm{kroonenb} /$ index htm]

Lederberg, A R, \& Mobley, C E (1990) The effect of hearing imparment on the qualıty of attachment and mother-loddler interaction Child Development, 61, $1596-1604$

Liotti, G (1992) Disorganized/disonented attachment in the etrology of the dissociative disorders Dissocia tion Progress in the Dissoctatve Disorders, 5, 196204

Lyons-Ruth, K (1996) Attachment relationships among children with aggressive behavior problems The role of disorganized early attachment patterns Journal of Consulting and Clinical Psychology, 64, 64-73

Lyons-Ruth, K, Alpern, L , \& Repacholı, B (1993) Disorganized infant attachment classification and mateinal psychosocial problems as predictors of hostıleagressive behavior in the preschool classroom Chuld Development, 64, 572-585

Lyons-Ruth, K , \& Block, D (1996) The disturbed caregiving system Relations among childhood trauma, maternal caregiving, and infant affect and attachment Infant Mental Health Journal, 17, 257-275

Lyons-Ruth, K, Connell, D B, Grunebaum, H U , \& Botein, S (1990) Infants at social risk Maternal depression and family support services as mediators of infant development and security of attachment Chtd Development, 61, 85-98

Lyons-Ruth, K, Connell, D B, Zoll, D, \& Stahl, J (1987) Infants at social risk Relations among infant maltreatment, maternal behavior, and infant attachment behavior Developmental Psychology, 23, 223232

Lyons-Ruth, K, Easterbrooks, M A , \& Cibell1, C D (1997) Infant attachment strategies, infant mental lag, and maternal depressive symptoms Predictors of $1 \mathrm{n}$ ternalızıng and extetnalizing problems at age $7 \mathrm{De}$ velopmental Psychology, 33, 681-692

Lyons-Ruth, K, Repacholl, B, McLeod, S, \& Silva, E (1991) Disorganized attachment behavior in infancy Short-term stability, maternal and intant correlates, and risk-1elated subtypes Development and Psycho pathology, 3, 377-396

Main, M (1990) Cross-cultural studies of attachment organization Recent studies, changing methodologies, and the concept of conditional strategies Human De velopment, 33, 48-61

Main, M , \& Cassidy, J (1988) Categories of response to reunion with the parent at age 6 Predictable fiom infant attachment classifications and stable over a 1month period Developmental Psychology, 24, 415426

Main, M , \& Hesse, E (1990) Parents' unresolved traumatıc experiences are ielated to infant disorganized attachment status Is frightened and/or frightening parental behavior the linking mechanism? In $\mathrm{M} T$ Greenberg, D Cicchett1, \& E M Cummings (Eds), Attachment in the preschool years Theory, research, and intervention (pp 161-18) Chicago and London University of Chicago Press

Main, M , Kaplan, N , \& Cassidy, J (1985) Security in infancy, childhood, and adulthood A move to the level of representation In I Bretherton \& $\mathrm{E}$ Waters (Eds), Growing points in attachment theory and research (pp 66-104) Monographs of the Society of Research in Child Development, 50 (Serial No 209)

Main, M , \& Morgan, H (1996) Disorganization and disortentation in infant strange situation behavior Phenotypic resemblance to dissociative states? In L M1chelson \& W Ray (Eds), Handbook of dissociation Theoretical, empirical and clinical perspectives (pp 107-138) New York Plenum

Man, M , \& Solomon, J (1986) Discovely of an insecure-disorganized/disoriented attachment pattern In T B Brazelton \& M W Yogman (Eds), Affective development in infancy (pp 95-124) Not wood, NJ Ablex

Main, M , \& Solomon, J (1990) Procedures for 1dentıfying infants as disorganized/disoriented durng the Ainsworth Strange Situation In M T Gieenberg, D Cicchetl1, \& E M Cummings (Eds), Attachment in the preschool years Theory, research, and intervention (pp 121-160) Chicago and London Univeisity of Chicago Press

Manassis, K, Bradley, S, Goldberg, S, Hood, J, \& Swinson, R P (1994) Attachment in mothers with anxiety disoideis and their children Journal of the American Academy of Chuld and Adolescent Psychtatry, 33, 1106-1113

Marcovitch, S, Goldbeıg, S A, Gold, A, Washıngton, J , Wasson, C, Krekewich, K, \& Handleyderry, M (1997) Determinants of behavioural problems in Romanian children adopted in Ontarıo Internatıonal Journal of Behavioral Development, 20, 17-31

Meins, E, Fernyhough, C, Russell, J , \& Cla1k-Carte1, D (1998) Security of attachment as a predictor of symbolic and mentalising abilities A longitudinal study Social Development, 7, 1-24

Milentijevic, I, Altman, S \& Waid, M J (1995, April) Adolescent mothers and their children Stabiluty of attachment organization from 1 to 35 years Paper presented at the Biennial Meeting of the Society for Research in Child Development, Indianapolis, IN

Moore, L, Crawford, F, Tucker, R, Lester, J , \& Fuller, S (1997) Maternal, child, and famly predictors of atypical attachment at 30 months Unpublished manuscript

Moss, E, Parent, S, Gosselın, C, Rousseau, D, \& St-Laurent, D (1996) Attachment and teacher reported behavior problems during the preschool and early school age period Development and Psychopathology, 8, 511-525

Moss, E, Rousseau, D, Parent, S, St-Laurent, D, \& Santonge, J (1998) Correlates of attachment at school-age Maternal reported stress, mother-child interaction and behavior problems Child Development, $69,1390-1405$ 
Mullen, B (1989) Advanced bastc meta-analysts H1llsdale, NJ Erlbaum

Murray, L (1992) The impact of postnatal depression on infant development Journal of Child Psychology and Psychiatry and Alled Disciplines, 33, 543-561

NICHD Early Child Care Research Network (1997) The effects of infant child care on infant-mother attachment security Results of the NICHD study of early child care Child Development, 68, 860-879

O'Connor, M J, Sigman, M \& \& Brill, N (1987) Disorganization of attachment in relation to maternal alcohol consumption Journal of Consulting and Clinical Psychology, 55 831-836

O'Connor, M J , Sigman, M D , \& Kasarı, C (1992) Atlachment behavior of infants exposed prenatally to alcohol Mediatıng effects of infant affect and mother-infant interaction Development and Psychopathology, 4, 243-256

Owen, M T, \& Cox, M J (1997) Marital conflict and the development of infant parent attachment relationships Journal of Family Psychology, 11, 152-164

Pederson, D R, Gleason, K E, Moran, G, \& Bento, S (1996) Maternal attachment representations, maternal sensitvity, and infant-mother attachment Unpublished manuscript, University of Toronto

Pipp-Siegel, S, Easterbrooks, M A, Brown, S R, \& Harmon, R J (1995) The relation between infants self mother knowledge and 3 attachment categories Infant Mental Health Journal, 16, 221-232

Pipp-Siegel, S, Siegel, C H, \& Dean, J (1997) Neurological aspects of the disorganized/disoriented attachment classification system Differentiating quality of the attachment relation ship from neurological impair ment Unpublished manuscript, University of Colorado at Boulder

Putnam, F W (1997) Dissociation in children and adolescents A developmental perspective New York Guilford

Radke-Yarrow, M, Cummings, E M, Kuczynskı, L , \& Chapman, M (1985) Patterns of attachment in twoand three-year-olds in normal families and families with parental depression Child Development, 56, 884-893

Radke-Yarrow, M, McCann, K, Demulder, E, Belmont, B , Martınez, P , \& Richardson, D T (1995) Attachment in the context of high-risk conditions Development and Psychopathology, 7, 247-265

Radloff, L (1977) The CES-D scale A self-report depression scale for lesearch in the general population Applied Psychological Measurement, I, 385-410

Rauh, H, Ziegenhain, U, Muller, B , \& Wiynroks, L (in press) Stability and change in infant-mother attachment in the second year of life Relations to parenting quality and varying degrees of daycare experience In P M Crittenden (Ed), The organization of attachment relationships Maturation, culture, and context Cambridge Cambridge University Press

Rodning, C, Beckwith, L, \& Howdrd, J (1989) Characteristıcs of dttachment organization and play organızation in prenatally drug-exposed toddlers Develop ment and Psychopathology, 1, 277-289

Rodnıng, C, Beckwith, L, \& Howard, J (1991) Qualıty of attachment and home environments in children prenatally exposed to PCP and cocane Special Issue Attachment and developmental psychopathology $D e$ velopment and Psychopathology, 3, 351-366

Rosenthal, R (1991) Meta-analytic procedures for social research Beverly Hills, CA Sage
Rosenthal, R (1995) Progress in Clinical Psychology Is There Any? Clinical Psychology-Sctence and Practice, 2, 133-150

Sag1, A, Van Ijzendoorn, M H , Aviezer, O, \& Donnell, F (1994) Sleeping out of home in a kibbutz communal arrangement It makes a difference for infantmother attachment Child Development, 65, 9921004

Schoelmerich, A, Lamb, M E, Leyendecker, B , \& Fracasso, M P (1997) Mother-infant teachıng interactions and attachment security in Euro-American and Central-American immigrant families Infant Behavlor \& Development, 20, 165-174

Schuengel, C, Bakermans-Kranenburg, M J , \& Van Ijzendoorn, M H (1999) Frughtening maternal behav1or linking unresolved loss and disorganized infant attachment Journal of Consulting and Clinical Psychology, 67, 54-63

Schuengel, C, Van Ijzendoorn, M H, Bakermans-Kranenburg, M J , \& Blom, M (1998) Frightenıng maternal behavior, unresolved loss, and disorganized infant attachment A pilot study Journal of Reproductive and Infant Psychology, 16, 277-283

Schwarzer, R (1989) Meta-analysts programs Unpublished manual, FU Berlın

Seifer, R, Sameroff, A J, Dicksteın, S, Keıtneı, G, Miller, I, Rasmussen, S, \& Hayden, L C (1996) Parental psychopathology, multiple contextual risks, and one-year outcomes in children Journal of Clintcal Child Psychology, 25, 423-435

Selfer, R, Schiller, M, Sameroff, A J, Resnick, S, \& Riordan, K (1996) Attachment, maternal sensitivity, and infant temperament during the furst year of life Developmental Psychology, 32, 12-25

Shaw, D S, Owens, E B, Vondrd, J I, Keenan, K, \& Winslow, E B (1996) Early risk factors and pathways in the development of early disruptive behavioi problems Development and Psychopathology, 8, 679-699

Sierra, A M (1989, April) The assessment of attachment in infants with mild to moderate cerebral palsy Paper presented at the Biennual Meeting of the Society for Research in Child Development, Kansas C1ty

Solomon, J, \& George, C (1994) Disorganization of maternal caregiving strategles An attachment approach to role reversal Paper presented at the 102nd Meeting of the American Psychological Association, Los Angeles, CA

Solomon, J, George, C, \& De Jong, A (1995) Children classified as controlling at age six Evidence of disorganized representational strategies and aggression at home and at school Development and Psychopathology, 7, 447-463

Spangler, G, Fremmer-Bombik, E , \& Grossmann, K (1996) Social and individual determinants of infant attachment security and disorganization Infunt Mental Health Journal, 17, 127-139

Spangler, G, \& Grossmann, K E (1993) Biobehavioral organization in securely and insecurely atlached infants Child Development, 64, 1439-1450

Speltz, M L, Endriga, M C, Fisher, P A , \& Mason, C A (1997) Early predictors of attachment in infants with cleft lip and/or palate Child Development, 68 , 12-25

Speltz, M L, Greenberg, M T, \& Deklyen, M (1990) Attachment in preschoolers with disruptive behavior A comparison of clinic-referred and nonpioblem children Development and Psychopathology, 2, 31-46 
Spıeker, S J , \& Bensley, L (1994) Roles of living arrangements and giandmother social suppoit in adolescent mothering and infant attachment Developmental Psychology, 30, 102-111

Sroufe, L A (1988) The 1ole of infant-caregivet attachment in development In $\mathbf{J}$ Belsky \& $\mathrm{T}$ Nezworskı (Eds ), Clintcal implications of attachment (pp 1838) Hillsdale, NJ Erlbaum

Steele, H, Stcele, M, \& Fondgy, P (1996a) Associatrons among attachment classifications of mothers, fatheis, and their infants Child Development, 67, 541555

Steele, H, Steele, M , \& Fonagy, P (1996b, Apı1) Attachment in the sixth year of life Paper presented at the Meetings of the International Congress of Psychology, Montreal, Canada

Tet, D M, Messinge, D S, Gelfand, D M, \& Isabella, $R$ (1995) Maternal depicssion and the quality of early attachment An examination of infants, preschoolers, and therr mothers Developmental Psychology, 31, 364-376

Thompson, $\mathrm{R}$ A (in press) Effects of attachment on later development In J Cassidy \& P Shaver (Eds), Handbook of attachment theory and research New Yolk Guilford

True, M (1994) Mother-infant attachment and conmuntcation among the Dogon of Malt Unpublished manuscript, Unıversity of Calıfounia at Beıkeley

Valenzuela, M (1990) Attachment in chionically undexweight young childien Chrld Development, 61, 19841996

Van Ijzendooın, M H (1995) Adult attachment ıepresentations, parental responsiveness, and infant attachment A meta-analysis on the predictive validity of the Adult Attachment Interview Psychological Bulletun, 117, 387-403

Van Ijzendooin, M H, \& DeWolff, M S (1997) In search of the absent father Meta-dnalyses on infantfather atlachment A rejoinder to ou discussants Child Development, 68, 604-609

Van Iyzendoorn, M H, Goldbeig, S, Kroonenberg, P M , \& Frenkel, O J (1992) The relative effects of maternal and child problems on the quality of atlachment A metd-analysis of attachment in clinical samples Child Development, 63, 840 858

Van Ijzendoorn, M H, \& Kioonenbelg, P M (1988) Cross-cultural patterns of atlachment A meta-analysis of the strange siluation Chld Development, 59, $147-156$
Van Ijzendoorn, M H, \& Schuengel, C (1996) The measurement of dissociation in normal and clinical populations Meta-analytic validation of the dissociative experiences scale (DES) Clmical Psychology Re vew, I6, 365-382

Vaughn, B E, Egeland, B R, Sioufe, L A, \& Wateı, E (1979) Individual differences in infant-mother attachment at twelve and eighteen months Stabihty and change in tamilies under stress Child Development 50, $971-975$

Vaughn, B E, Goldberg, S, Atkinson, L, \& Matcovitch, S (1994) Quality of toddler-mother attachment in childien with Down syndiome Limits to interpretation of strange situation behavios Child Development, $65,95-108$

Vondra, J I, Hommording, K D , \& Shaw, D S (1997) Stabthty and change in infant attachment in a low income sample Unpublished manuscript, Pittsburgh Univet stly

Ward, M J, \& Carlson, E A (1995) Associations among adult attachment presentations, maternal sens1t1vity, and infant-mother attachment in a sample of adolescent mothers Chuld Development, 66, 69-79

Ward, M J, Kessleı, D B, \& Altman, S C (1993) Infant-mother attachment in children with faluse to thrive Infant Mental Health Journal, 14, 208-220

Wattne, U G, Giossmann, K, Fremme1-Bombık, E, \& Suess, G (1994) Attachment patteins at age six in South Geimany Piedictability fiom infancy and implications for preschool behavior Child Development, $65,1014-1027$

Willemsen, S H V, Bakeımans-Kranenburg, M J, Bu1telaar, J K, Van Ijzendooin, M H, \& Van Engeland, H (1998) Insecure and disorganized attachment in children with autistic behavior Related to soctal in teraction and heart rate Unpublished manuscipt, Utrecht University

Zeanah, C H, Borı, N W, \& Lan11eu, J A (1997) Infant development and developmental risk A review of the past 10 years Joumal of the Amesican Acadeny of Child and Adolescent Psichuatry, 36165 178

Zeanah, C H, Bous, N W, \& Scheetnga, M S (1997) Psychopathology in infancy Journal of Chrld Psychology and Psychatry and Alled Disciplines, 38, 81-99

Zevalkınk, J (1997) Attachment in Indonesia The mother-chld relationship in context Ridderkerk, The Netherland, Riddeipint 